\title{
LEVEL II SCOUR ANALYSIS FOR BRIDGE 31 (JERITH00350031) on TOWN HIGHWAY 35, crossing MILL BROOK, JERICHO, VERMONT
}

Open-File Report 97-767

Prepared in cooperation with

VERMONT AGENCY OF TRANSPORTATION and

FEDERAL HIGHWAY ADMINISTRATION

U.S. Department of the Interior

U.S. Geological Survey

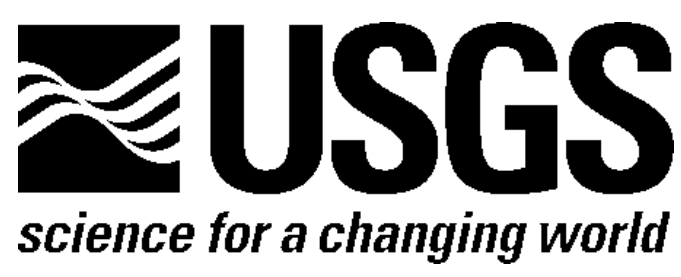




\section{LEVEL II SCOUR ANALYSIS FOR BRIDGE 31 (JERITH00350031) on TOWN HIGHWAY 35, crossing MILL BROOK, JERICHO, VERMONT By EMILY C. WILD}

U.S. Geological Survey Open-File Report 97-767

Prepared in cooperation with

VERMONT AGENCY OF TRANSPORTATION and

FEDERAL HIGHWAY ADMINISTRATION 


\title{
U.S. DEPARTMENT OF THE INTERIOR BRUCE BABBITT, Secretary
}

\author{
U.S. GEOLOGICAL SURVEY \\ Mark Schaefer, Acting Director
}

For additional information write to:

District Chief

U.S. Geological Survey 361 Commerce Way

Pembroke, NH 03275-3718
Copies of this report may be purchased from:

U.S. Geological Survey

Branch of Information Services

Open-File Reports Unit

Box 25286

Denver, CO 80225-0286 


\section{CONTENTS}

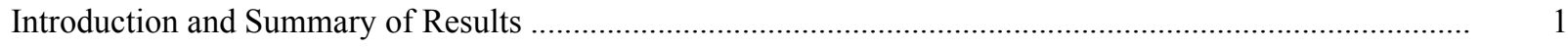

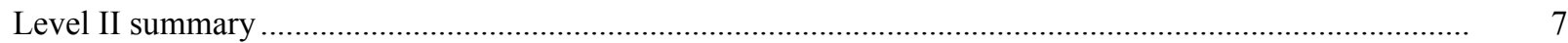

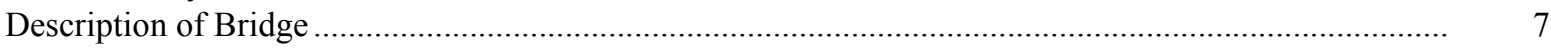

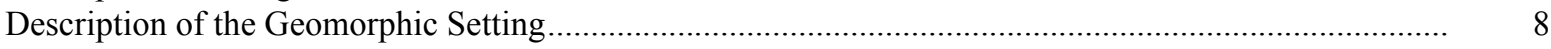

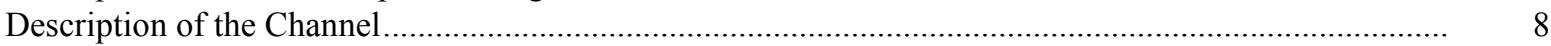

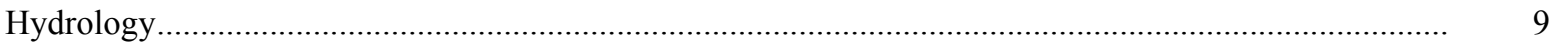

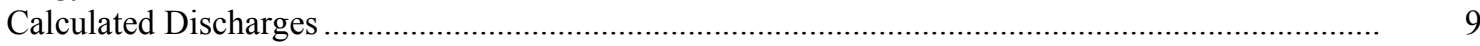

Description of the Water-Surface Profile Model (WSPRO) Analysis ......................................................... 10

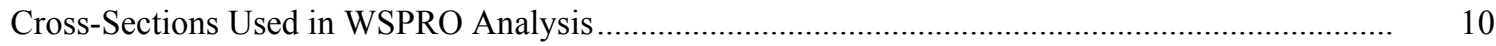

Data and Assumptions Used in WSPRO Model ...........................................................................

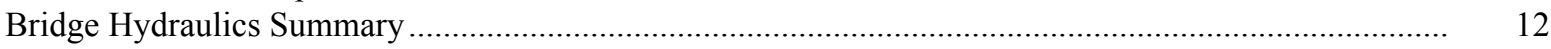

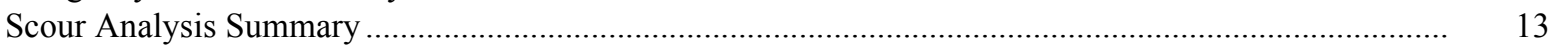

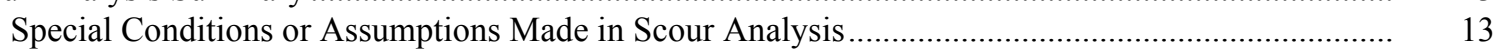

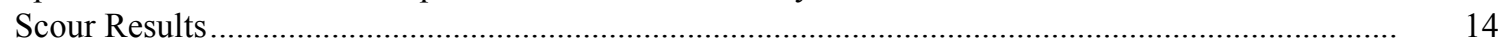

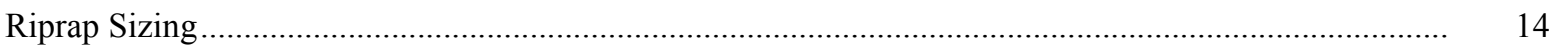

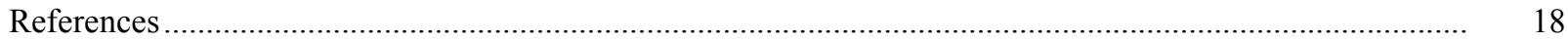

Appendixes:

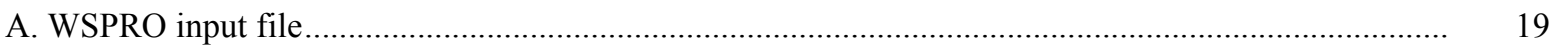

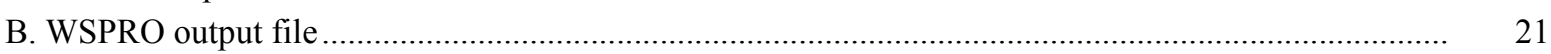

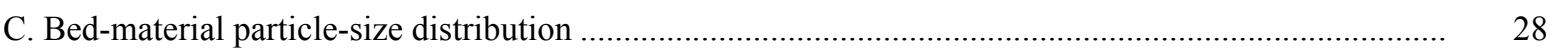

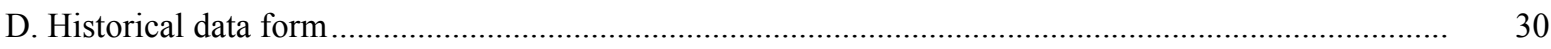

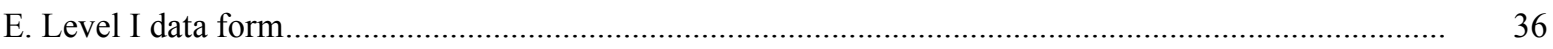

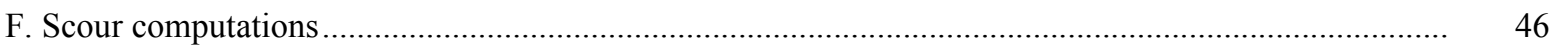

\section{FIGURES}

1. Map showing location of study area on USGS 1:24,000 scale map ........................................................

2. Map showing location of study area on Vermont Agency of Transportation town

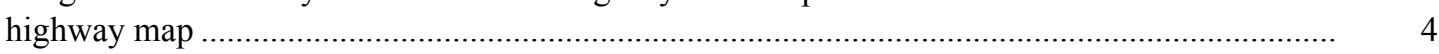

3. Structure JERITH00350031 viewed from upstream (July 3, 1996) ………............................................ 5

4. Downstream channel viewed from structure JERITH00350031 (July 3, 1996)....................................... 5

5. Upstream channel viewed from structure JERITH00350031 (July 3, 1996).............................................. 6

6. Structure JERITH00350031 viewed from downstream (July 3, 1996). ................................................... 6

7. Water-surface profiles for the 100- and 500-year discharges at structure JERITH00350031 on Town Highway 35, crossing Mill Brook, Jericho, Vermont.

8. Scour elevations for the 100- and 500-year discharges at structure

JERITH00350031 on Town Highway 35, crossing Mill Brook,

Jericho, Vermont.

\section{TABLES}

1. Remaining footing/pile depth at abutments for the 100-year discharge at structure JERITH00350031 on Town Highway 35, crossing Mill Brook, Jericho, Vermont.

2. Remaining footing/pile depth at abutments for the 500-year discharge at structure JERITH00350031 on Town Highway 35, crossing Mill Brook,

Jericho, Vermont. 


\begin{tabular}{lcl}
\hline Multiply & By & To obtain \\
\hline & Length & \\
inch (in.) & 25.4 & millimeter $(\mathrm{mm})$ \\
foot $(\mathrm{ft})$ & 0.3048 & meter $(\mathrm{m})$ \\
mile (mi) & 1.609 & kilometer $(\mathrm{km})$ \\
& Slope & \\
foot per mile $(\mathrm{ft} / \mathrm{mi})$ & 0.1894 & meter per $\mathrm{kilometer}(\mathrm{m} / \mathrm{km})$ \\
& Area & \\
square mile $\left(\mathrm{mi}^{2}\right)$ & 2.590 & square $\mathrm{kilometer}\left(\mathrm{km}{ }^{2}\right)$ \\
& Volume & \\
cubic foot $\left(\mathrm{ft}^{3}\right)$ & 0.02832 & cubic meter $\left(\mathrm{m}^{3}\right)$ \\
& Velocity and Flow & \\
foot per second $(\mathrm{ft} / \mathrm{s})$ & 0.3048 & meter per second $(\mathrm{m} / \mathrm{s})$ \\
cubic foot per second $\left(\mathrm{ft}^{3} / \mathrm{s}\right)$ & 0.02832 & cubic meter per second $\left(\mathrm{m}^{3} / \mathrm{s}\right)$ \\
cubic foot per second per & 0.01093 & cubic meter per \\
square mile & & second per square \\
{$\left[\left(\mathrm{ft}^{3} / \mathrm{s}\right) / \mathrm{mi}^{2}\right]$} & & kilometer $\left[\left(\mathrm{m}^{3} / \mathrm{s}\right) / \mathrm{km}^{2}\right]$
\end{tabular}

OTHER ABBREVIATIONS

\begin{tabular}{|c|c|c|c|}
\hline $\mathrm{BF}$ & bank full & LWW & left wingwall \\
\hline cfs & cubic feet per second & $\mathrm{MC}$ & main channel \\
\hline $\mathrm{D}_{50}$ & median diameter of bed material & RAB & right abutment \\
\hline DS & downstream & RABUT & face of right abutment \\
\hline elev. & elevation & $\mathrm{RB}$ & right bank \\
\hline $\mathrm{f} / \mathrm{p}$ & flood plain & ROB & right overbank \\
\hline $\mathrm{ft}^{2}$ & square feet & RWW & right wingwall \\
\hline $\mathrm{ft} / \mathrm{ft}$ & feet per foot & $\mathrm{TH}$ & town highway \\
\hline JCT & junction & UB & under bridge \\
\hline LAB & left abutment & US & upstream \\
\hline LABUT & face of left abutment & USGS & United States Geological Survey \\
\hline LB & left bank & VTAOT & Vermont Agency of Transportation \\
\hline LOB & left overbank & WSPRO & water-surface profile model \\
\hline
\end{tabular}

In this report, the words "right" and "left" refer to directions that would be reported by an observer facing downstream.

Sea level: In this report, "sea level" refers to the National Geodetic Vertical Datum of 1929-- a geodetic datum derived from a general adjustment of the first-order level nets of the United States and Canada, formerly called Sea Level Datum of 1929. 


\title{
LEVEL II SCOUR ANALYSIS FOR BRIDGE 31 (JERITH00350031) ON TOWN HIGHWAY 35, CROSSING MILL BROOK, JERICHO, VERMONT
}

\author{
By Emily C. Wild
}

\section{INTRODUCTION AND SUMMARY OF RESULTS}

This report provides the results of a detailed Level II analysis of scour potential at structure JERITH00350031 on Town Highway 35 crossing Mill Brook, Jericho, Vermont (figures 18). A Level II study is a basic engineering analysis of the site, including a quantitative analysis of stream stability and scour (U.S. Department of Transportation, 1993). Results of a Level I scour investigation also are included in Appendix E of this report. A Level I investigation provides a qualitative geomorphic characterization of the study site. Information on the bridge, gathered from Vermont Agency of Transportation (VTAOT) files, was compiled prior to conducting Level I and Level II analyses and is found in Appendix D.

The site is in the Green Mountain section of the New England physiographic province and the Champlain section of the St. Lawrence physiographic province in northwestern Vermont. The $15.7-\mathrm{mi}^{2}$ drainage area is in a predominantly rural and forested basin. In the vicinity of the study site, the surface cover is forest upstream of the bridge. The downstream left overbank is pasture. The downstream right overbank is brushland.

In the study area, the Mill Brook has an incised, sinuous channel with a slope of approximately $0.02 \mathrm{ft} / \mathrm{ft}$, an average channel top width of $117 \mathrm{ft}$ and an average bank height of $11 \mathrm{ft}$. The channel bed material ranges from gravel to boulders with a median grain size $\left(\mathrm{D}_{50}\right)$ of $81.1 \mathrm{~mm}(0.266 \mathrm{ft})$. The geomorphic assessment at the time of the Level I and Level II site visit on July 3, 1996, indicated that the reach was laterally unstable.

The Town Highway 35 crossing of the Mill Brook is a 53-ft-long, one-lane bridge consisting of a 50-foot steel-beam span with a wooden deck (Vermont Agency of Transportation, written communication, November 30, 1995). The opening length of the structure parallel to the bridge face is $48 \mathrm{ft}$. The bridge is supported by a vertical, concrete abutment with wingwalls on the left. On the right, the abutment and wingwalls are laid-up stone with a concrete cap. The channel is not skewed to the opening. The roadway is skewed 10 degrees to the opening. 
A scour hole $1.5 \mathrm{ft}$ deeper than the mean thalweg depth was observed along the left abutment during the Level I assessment. Scour countermeasures at the site were type-2 stone fill (less than 36 inches diameter) at the upstream and downstream left wingwalls, the upstream and downsteam left channel banks, and the downstream left road embankment. Additional details describing conditions at the site are included in the Level II Summary and Appendices D and E.

Scour depths and recommended rock rip-rap sizes were computed using the general guidelines described in Hydraulic Engineering Circular 18 (Richardson and others, 1995). In addition, the incipient roadway-overtopping discharge is analyzed since it has the potential of being the worst-case scour scenario. Total scour at a highway crossing is comprised of three components: 1) long-term streambed degradation; 2) contraction scour (due to accelerated flow caused by a reduction in flow area at a bridge) and; 3) local scour (caused by accelerated flow around piers and abutments). Total scour is the sum of the three components. Equations are available to compute depths for contraction and local scour and a summary of the results of these computations follows.

Contraction scour for all modelled flows ranged from 0.4 to $1.3 \mathrm{ft}$. The worst-case contraction scour occurred at the 500-year discharge. Left abutment scour ranged from 9.9 to $12.4 \mathrm{ft}$. Right abutment scour ranged from 13.8 to $17.8 \mathrm{ft}$. The worst-case abutment scour occurred at the 500-year discharge. Additional information on scour depths and depths to armoring are included in the section titled "Scour Results". Scoured-streambed elevations, based on the calculated scour depths, are presented in tables 1 and 2. A cross-section of the scour computed at the bridge is presented in figure 8. Scour depths were calculated assuming an infinite depth of erosive material and a homogeneous particle-size distribution.

It is generally accepted that the Froehlich equation (abutment scour) gives "excessively conservative estimates of scour depths" (Richardson and others, 1995, p. 47). Usually, computed scour depths are evaluated in combination with other information including (but not limited to) historical performance during flood events, the geomorphic stability assessment, existing scour protection measures, and the results of the hydraulic analyses. Therefore, scour depths adopted by VTAOT may differ from the computed values documented herein. 


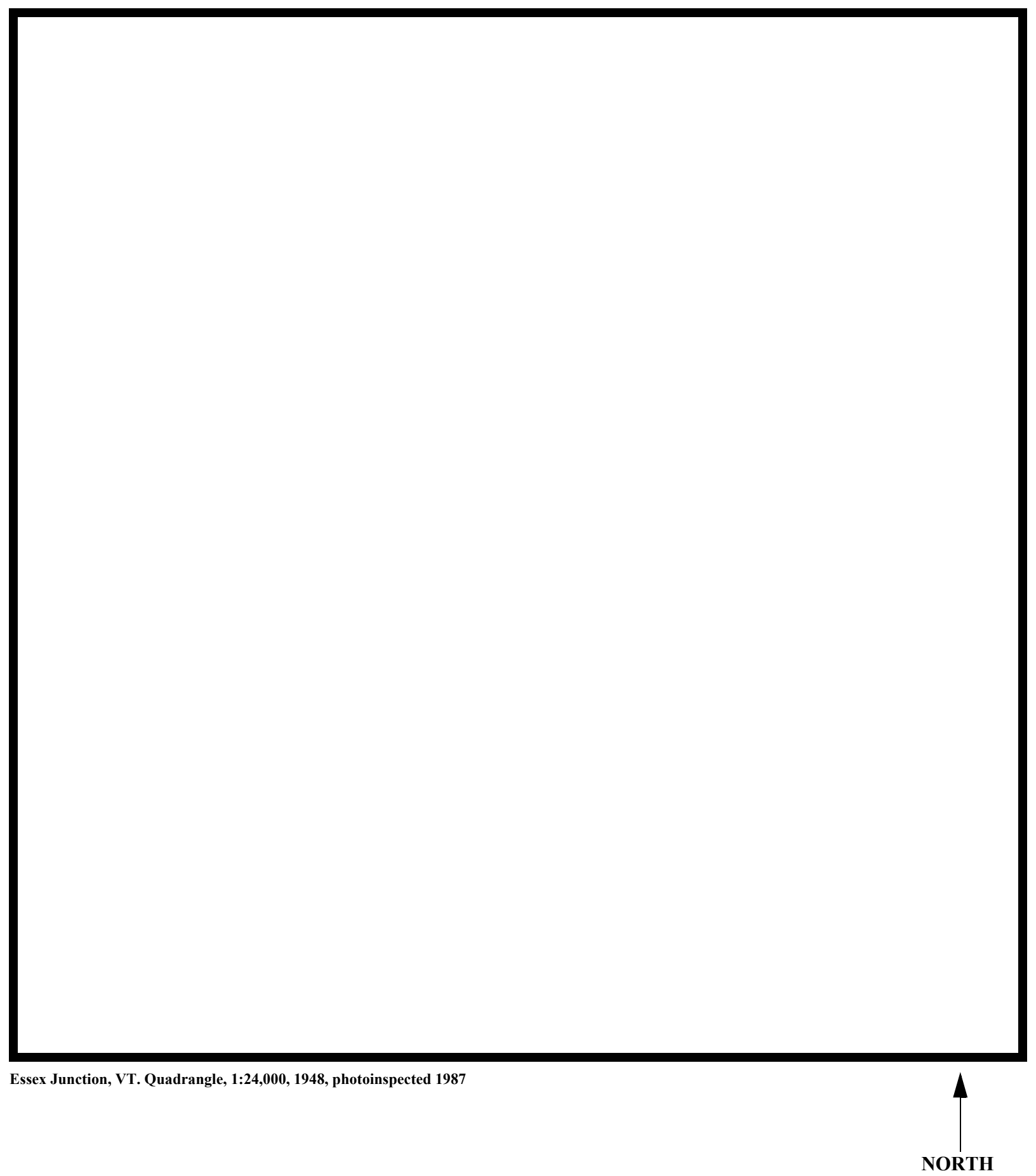

Figure 1. Location of study area on USGS 1:24,000 scale map. 
Figure 2. Location of study area on Vermont Agency of Transportation town highway map. 


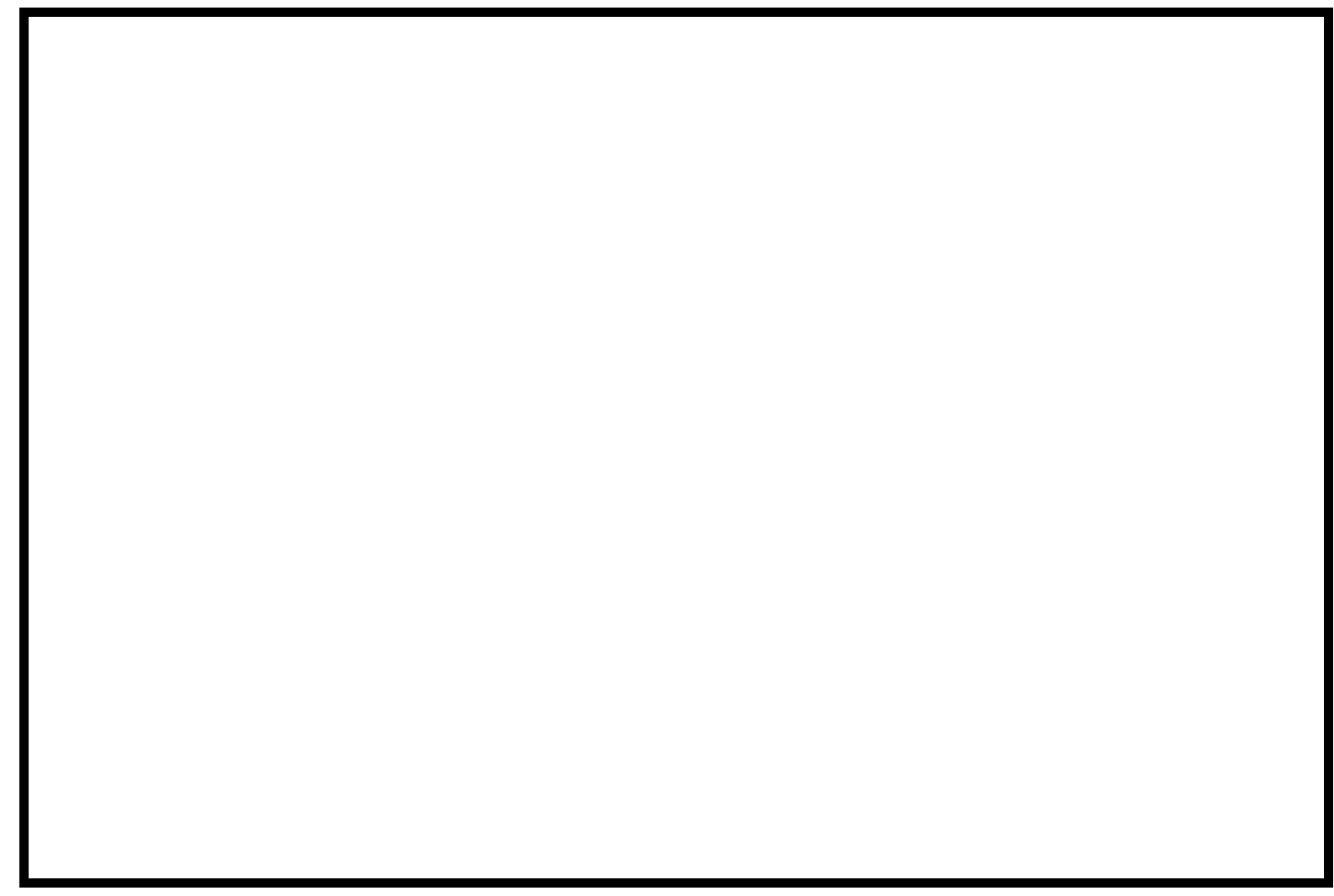

Figure 3. Structure JERITH00350031 viewed from upstream (July 3, 1996). 


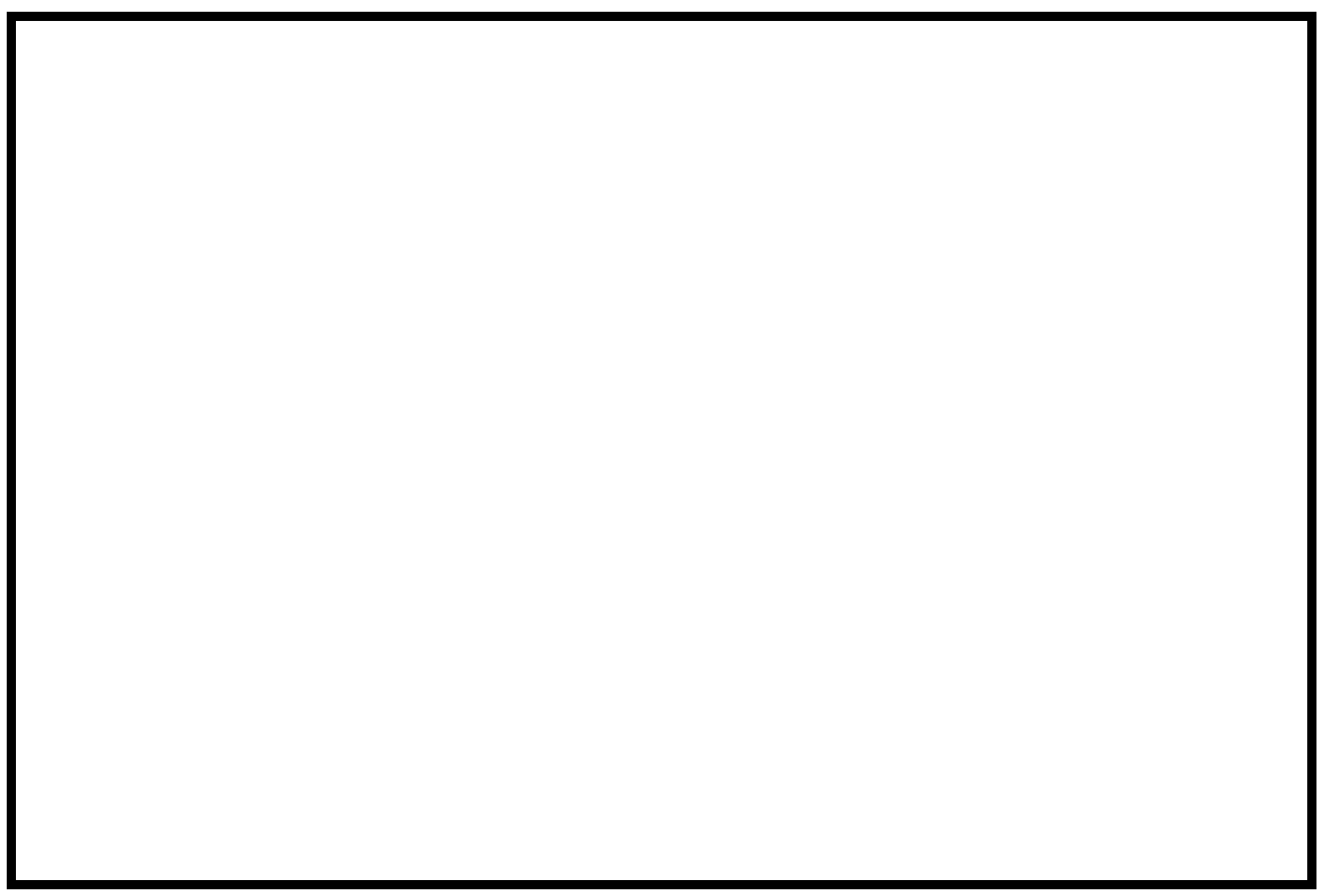

Figure 5. Upstream channel viewed from structure JERITH00350031 (July 3, 1996). 


\section{LEVEL II SUMMARY}

\begin{tabular}{llllll} 
Structure Number & JERITH00350031 & Stream & \multicolumn{2}{c}{ Mill Brook } & \\
& & & & \\
County & Chittenden & Road & TH35 & District & 5
\end{tabular}

\section{Description of Bridge}

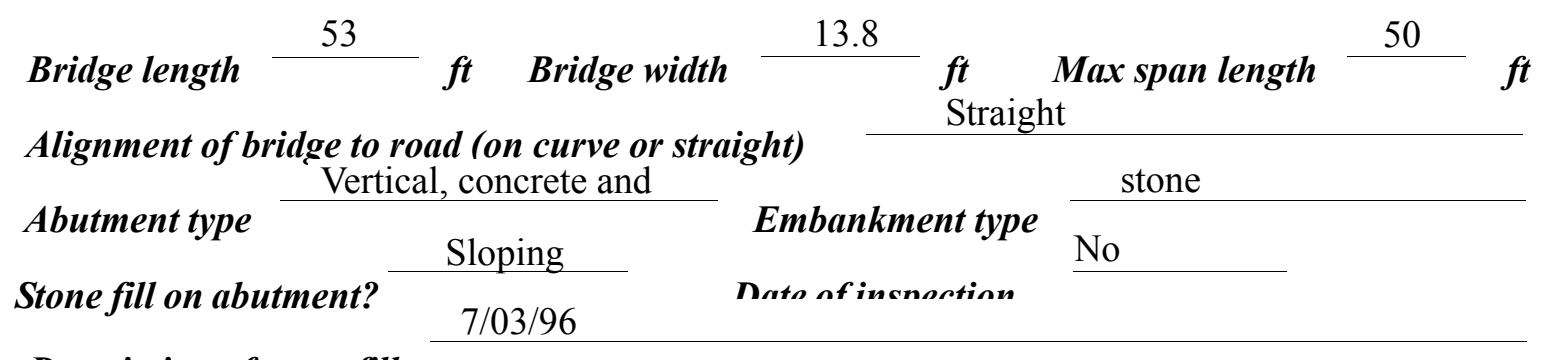

namanintine. af atams fill

$7 / 03 / 96$

Type-2, around the upstream and downstream left wingwalls.

Left abutment and left wingwalls are concrete. Right abutment and right wingwalls laid-up stone with a concrete cap. There is a one and a half foot deep scour hole in front of the left abutment.

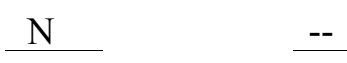

Is bridge skewed to flood flow according to $\mathrm{N} \quad$ 'survey? Angle

However, the channel mildly bends in the upstream reach, as well as the downstream reach.

$7 / 03 / 96$

Debris accumulation on bridge at time of Level I or Level II site visit:

$$
\begin{gathered}
\text { Date af insnortion } \\
\underline{0}
\end{gathered} \quad \begin{gathered}
\text { Percent of ahrmanal } \\
\text { bloeked inortzontatly }
\end{gathered}
$$

Level I

Level II

$$
96
$$

High. In the upstream reach, there is a log across the channel, and some dead trees leaning into the channel at the location of the cut-bank.

Potential for debris

The Level I assessment noted no features affecting the flow at or near the bridge during the July Doscriho any foaturos noar ar at tho hridoo that mav' affort flow, (includo ahsorvation dato) 3, 1996 site visit. 


\section{Description of the Geomorphic Setting}

General topography The channel is located within a moderate relief valley with a narrow, irregualr flood plain.

Geomorphic conditions at bridge site: downstream (DS), upstream (US)

Date of inspection $\quad 7 / 03 / 96$

DS left: $\quad$ Moderately sloped overbank.

DS right: Steep channel bank to a narrow flood plain.

US left: $\quad$ Steep channel bank with a moderately sloped overbank.

US right: $\quad$ Narrow flood plain to a moderately sloped overbank.

\section{Description of the Channel}

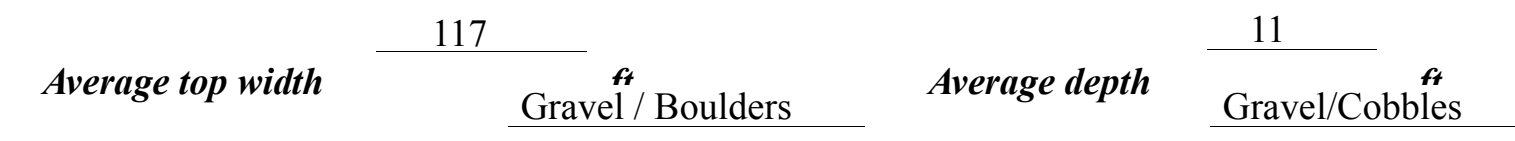

Predominant bed material

Bank material

Sinuous and laterally

unstable with non-alluvial channel boundäries and a narrow floö plain.

$7 / 03 / 96$

Vegetative co ${ }^{1}$ Lawn.

DS left: $\quad$ Brushland.

DS right: $\quad$ Trees and brush.

US left: $\quad$ Trees and brush.

US right: $\quad$ N

Do banks appear stable? Light fluvial erosion has resulted in cut-banks upstream and downstream of the bridge. The point bars in the channel are vegetated with small bushes and
date of observatton. grass. The extent of these point bars can be found discussed in further detail in Appendix E.

The July 3, 1996 Level I assessment and written communication with the VTAOT, November 30, 1995, have indicated

the point bar along the right side of the channel blocks $2 / 3$ of the channel flow under the bridge. Describe any obstructions in channel and date of observation. 


\section{Hydrology}

Drainage area $\stackrel{15.7}{\mathrm{mi}^{2}}$

Percentage of drainage area in physiographic provinces: (approximate)

Physiographic province/section New England/ Green Mountain

St. Lawrence Valley/ Champlain
Percent of drainage area 80

20

Is drainage area considered rural or urban?

Rural None.

urbanization:

Is there a USGS gage on the stream of interest?

No

USGS gage description

USGS gage number

Gage drainage area $\mathrm{mi}^{2}$

Describe any significant

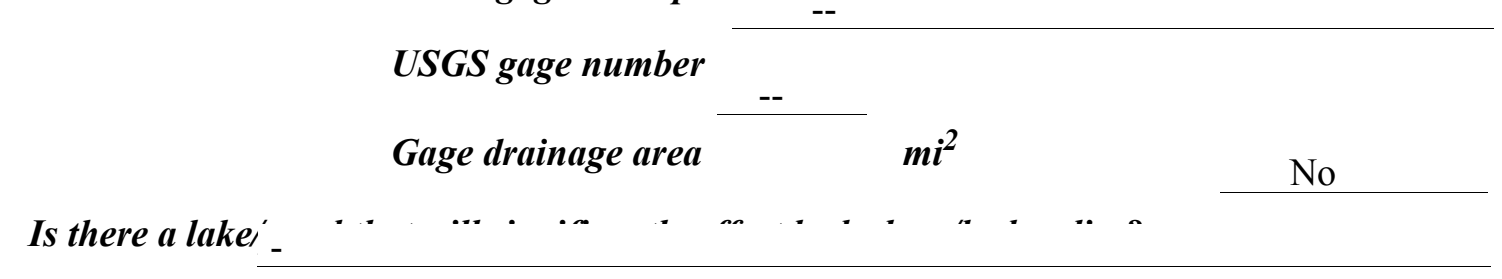

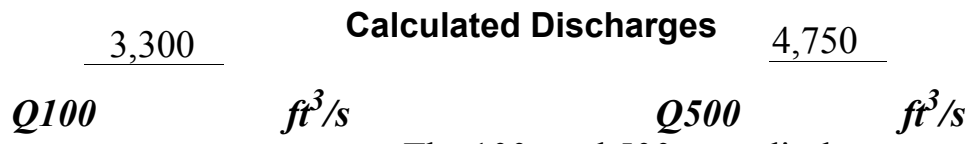

The 100- and 500-year discharges are based on

VTAOT flood frequency estimates for this site available from the VTAOT database. The values computed are within a range defined by several empirical flood frequency curves (Benson, 1962; Johnson and Tasker, 1974; FHWA, 1983; Potter, 1957a\&b; Talbot, 1887). 


\section{Description of the Water-Surface Profile Model (WSPRO) Analysis}

Datum for WSPRO analysis (USGS survey, sea level, VTAOT plans) ～USGS survey

Datum tie between USGS survey and VTAOT plans

To obtain VTAOT datum, subtract

161.5 feet from USGS arbitrary survey datum.

Description of reference marks used to determine USGS datum. $\quad$ RM1 is a chiseled X on

top of the downstream end of the left bridge backwall (elev. $499.34 \mathrm{ft}$, arbitrary survey datum).

RM2 is a chiseled X on top of the upstream end of the right bridge backwall (elev. $499.22 \mathrm{ft}$, arbitrary survey datum).

Cross-Sections Used in WSPRO Analysis

\begin{tabular}{|c|c|c|c|}
\hline${ }^{1}$ Cross-section & $\begin{array}{c}\text { Section } \\
\text { Reference } \\
\text { Distance } \\
\text { (SRD) in feet }\end{array}$ & $\begin{array}{c}{ }^{2} \text { Cross-section } \\
\text { development }\end{array}$ & Comments \\
\hline EXITX & -48 & 1 & Exit section \\
\hline FULLV & 0 & 2 & $\begin{array}{l}\text { Downstream Full-valley } \\
\text { section (Templated from } \\
\text { EXITX) }\end{array}$ \\
\hline BRIDG & 0 & 1 & Bridge section \\
\hline RDWAY & 8 & 1 & Road Grade section \\
\hline APPRO & 63 & 2 & $\begin{array}{l}\text { Modelled Approach sec- } \\
\text { tion (Templated from } \\
\text { APTEM) }\end{array}$ \\
\hline APTEM & 68 & 1 & $\begin{array}{l}\text { Approach section as sur- } \\
\text { veyed (Used as a tem- } \\
\text { plate) }\end{array}$ \\
\hline
\end{tabular}

${ }^{1}$ For location of cross-sections see plan-view sketch included with Level I field form, Appendix E. For more detail on how cross-sections were developed see WSPRO input file. 


\section{Data and Assumptions Used in WSPRO Model}

Hydraulic analyses of the reach were done by use of the Federal Highway Administration's WSPRO step-backwater computer program (Shearman and others, 1986, and Shearman, 1990). The analyses reported herein reflect conditions existing at the site at the time of the study. Furthermore, in the development of the model it was necessary to assume no accumulation of debris or ice at the site. Results of the hydraulic model are presented in the Bridge Hydraulic Summary, Appendix B, and figure 7.

Channel roughness factors (Manning's “ $n$ ”) used in the hydraulic model were estimated using field inspections at each cross section following the general guidelines described by Arcement and Schneider (1989). Final adjustments to the values were made during the modelling of the reach. Channel " $\mathrm{n}$ " values for the reach ranged from 0.055 to 0.080 , and overbank " $\mathrm{n}$ " values ranged from 0.045 to 0.095 .

Normal depth at the exit section (EXITX) was assumed as the starting water surface. This depth was computed by use of the slope-conveyance method outlined in the user's manual for WSPRO (Shearman, 1990). The slope used was $0.0194 \mathrm{ft} / \mathrm{ft}$ which was calculated from thalweg slopes surveyed downstream.

The surveyed approach section (APTEM) was moved along the approach channel slope $(0.0297 \mathrm{ft} / \mathrm{ft})$ to establish the modelled approach section (APPRO), one bridge length upstream

of the upstream face as recommended by Shearman and others (1986). This approach also provides a consistent method for determining scour variables. 


\section{Bridge Hydraulics Summary}

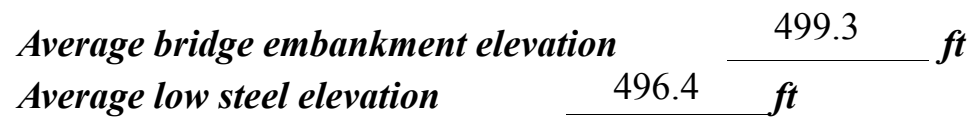

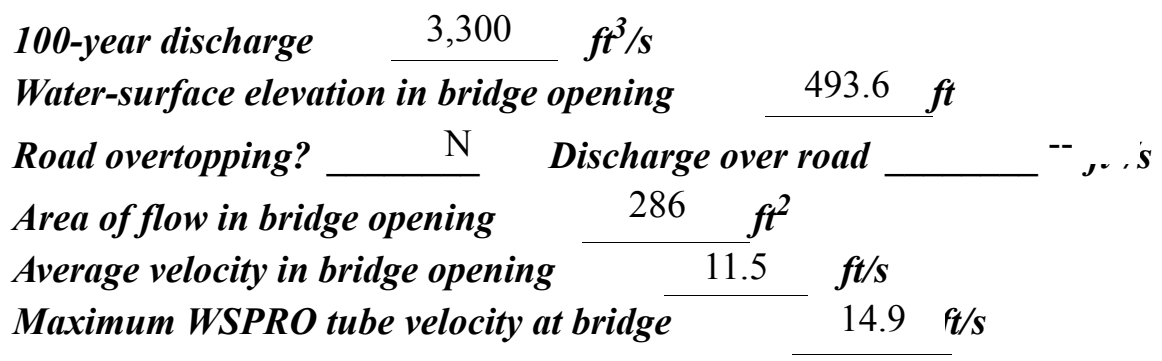

Water-surface elevation at Approach section with bridge Water-surface elevation at Approach section without bridge 496.2 Amount of backwater caused by bridge

$0.9 \quad i$

500-year discharge $\quad 4,750 \quad \mathrm{ft}^{3} / \mathrm{s}$

Water-surface elevation in bridge opening $496.4 f t$

Road overtopping? ___ Y Discharge over road __ $182 \mathrm{ft}^{3} / \mathrm{s}$

Area of flow in bridge opening $\quad 419 \quad \mathrm{ft}^{2}$

Average velocity in bridge opening $10.9 \mathrm{ft} / \mathrm{s}$

Maximum WSPRO tube velocity at bridge 13.5 , $s$

Water-surface elevation at Approach section with bridge

Water-surface elevation at Approach section without bridge

Amount of backwater caused by bridge

3.4

500.0

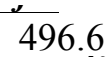

Incipient overtopping discharge $\quad 4,330 \quad \mathrm{ft}^{3} / \mathrm{s}$

Water-surface elevation in bridge opening $496.4 \quad t$

Area of flow in bridge opening

$419 \mathrm{ft}^{2}$

Average velocity in bridge opening

2

Maximum WSPRO tube velocity at bridge

$10.3 \mathrm{ft} / \mathrm{s}$

$12.7 \mathrm{ft} / \mathrm{s}$

Water-surface elevation at Approach section with bridge

Water-surface elevation at Approach section without bridge

499.5

Amount of backwater caused by bridge

$3.3 \quad$ it




\section{Scour Analysis Summary}

\section{Special Conditions or Assumptions Made in Scour Analysis}

Scour depths were computed using the general guidelines described in Hydraulic Engineering Circular 18 (Richardson and others, 1995). Scour depths were calculated assuming an infinite depth of erosive material and a homogeneous particle-size distribution. The results of the scour analysis are presented in tables 1 and 2 and a graph of the scour depths is presented in figure 8 .

Contraction scour for the 100-year discharge was computed by use of Laursen's clear-water contraction scour equation (Richardson and others, 1995, p. 32, equation 20). At this site, the 500-year and incipient roadway-overtopping discharges resulted in unsubmerged orifice flow. Contraction scour at bridges with orifice flow is best estimated by use of the Chang pressure-flow scour equation (oral communication, J. Sterling Jones, October 4, 1996). Thus, contraction scour was computed by use of the Chang equation (Richardson and others, 1995, p. 145-146). Results of 100-year and 500-year analysis are presented in figure 8 and tables 1 and 2 . The streambed armoring depths computed suggest that armoring will not limit the depth of contraction scour.

Additional estimates of contraction scour for the 500-year and incipient roadwayovertopping also were computed by use of Laursen's clear-water scour equation (Richardson and others, 1995, p. 32, equation 20) and the results are presented in Appendix F. Furthermore, for those discharges resulting in unsubmerged orifice flow, contraction scour was computed by substituting alternative estimates for the depth of flow in the bridge at the downstream face in the Chang equation and Laursen's clear-water equation. Contraction scour results with respect to these substitutions also are provided in Appendix F.

Abutment scour was computed for the left and right abutments by use of the Froehlich equation (Richardson and others, 1995, p. 48, equation 28). Variables for the Froehlich equation include the Froude number of the flow approaching the embankments, the length of the embankment blocking flow, and the depth of flow approaching the embankment less any roadway overtopping. 


\section{Scour Results}

100-yr discharge 500-yr discharge

Contraction scour:

(Scour depths in feet)

Main channel

Live-bed scour

Clear-water scour

Depth to armoring

Left overbank

Right overbank

Local scour:

Abutment scour

Left abutment

12.4

12.1

13.8

17.8

17.1-

Right abutment

Pier scour

Pier 1

Pier 2

$11.68 .7^{-}$

$---$

--

$9.9^{-}$

overtopping

discharge

Pier 3

\section{Riprap Sizing}

Abutments:

Left abutment

Right abutment

Piers:

Pier 1

Pier 2

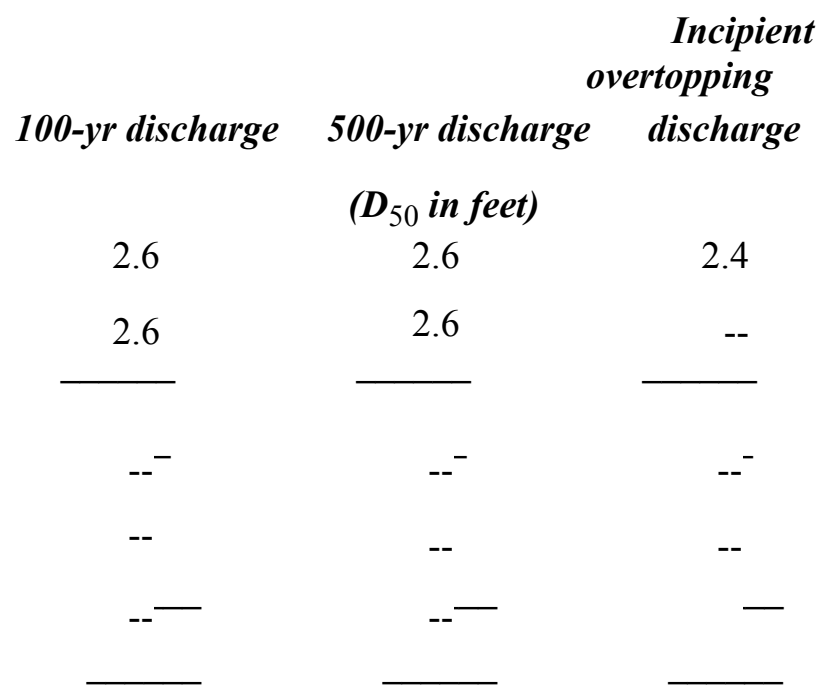




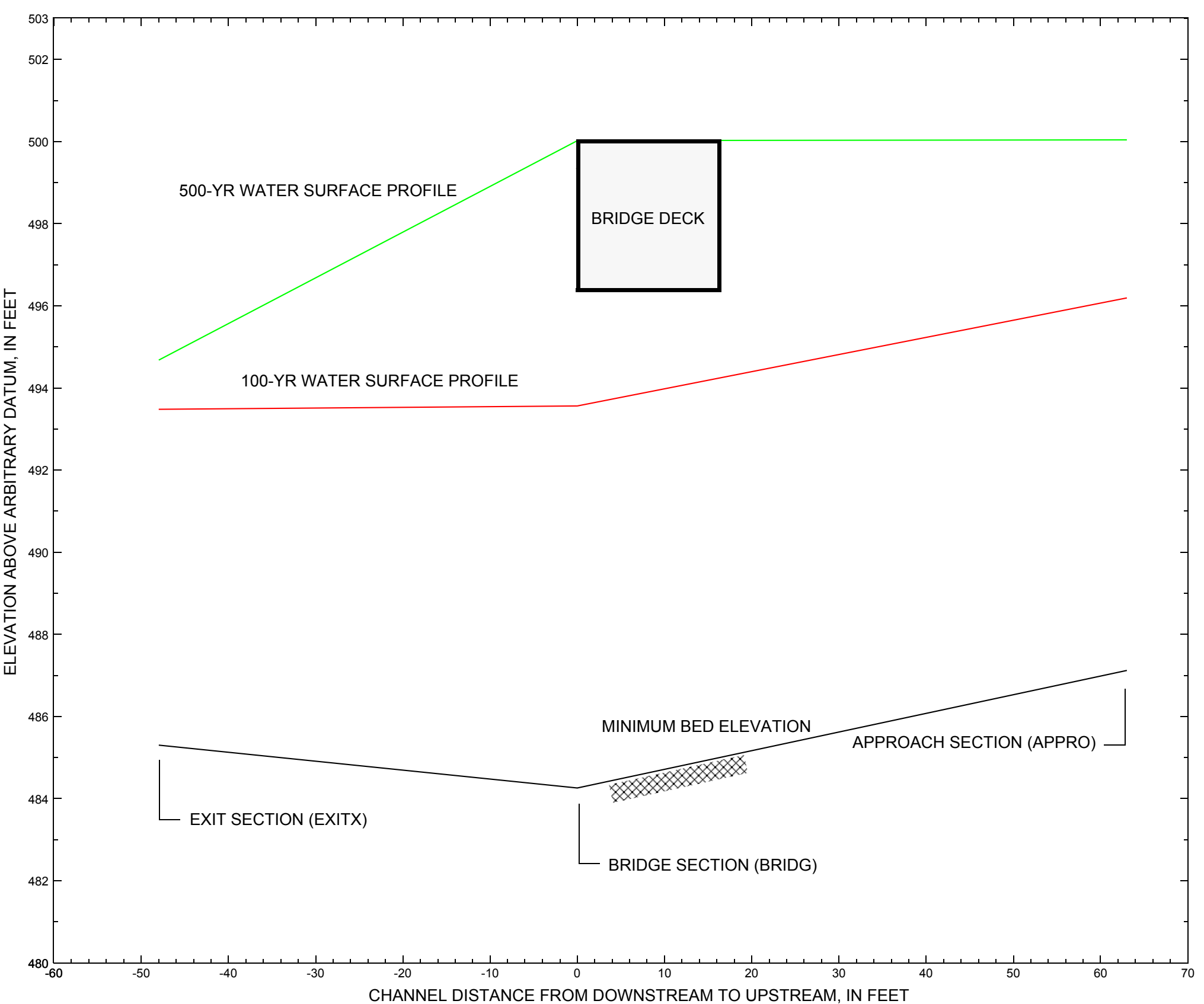

Figure 7. Water-surface profiles for the 100- and 500-yr discharges at structure JERITH00350031 on Town Highway 35, crossing Mill Brook, Jericho, Vermont. 


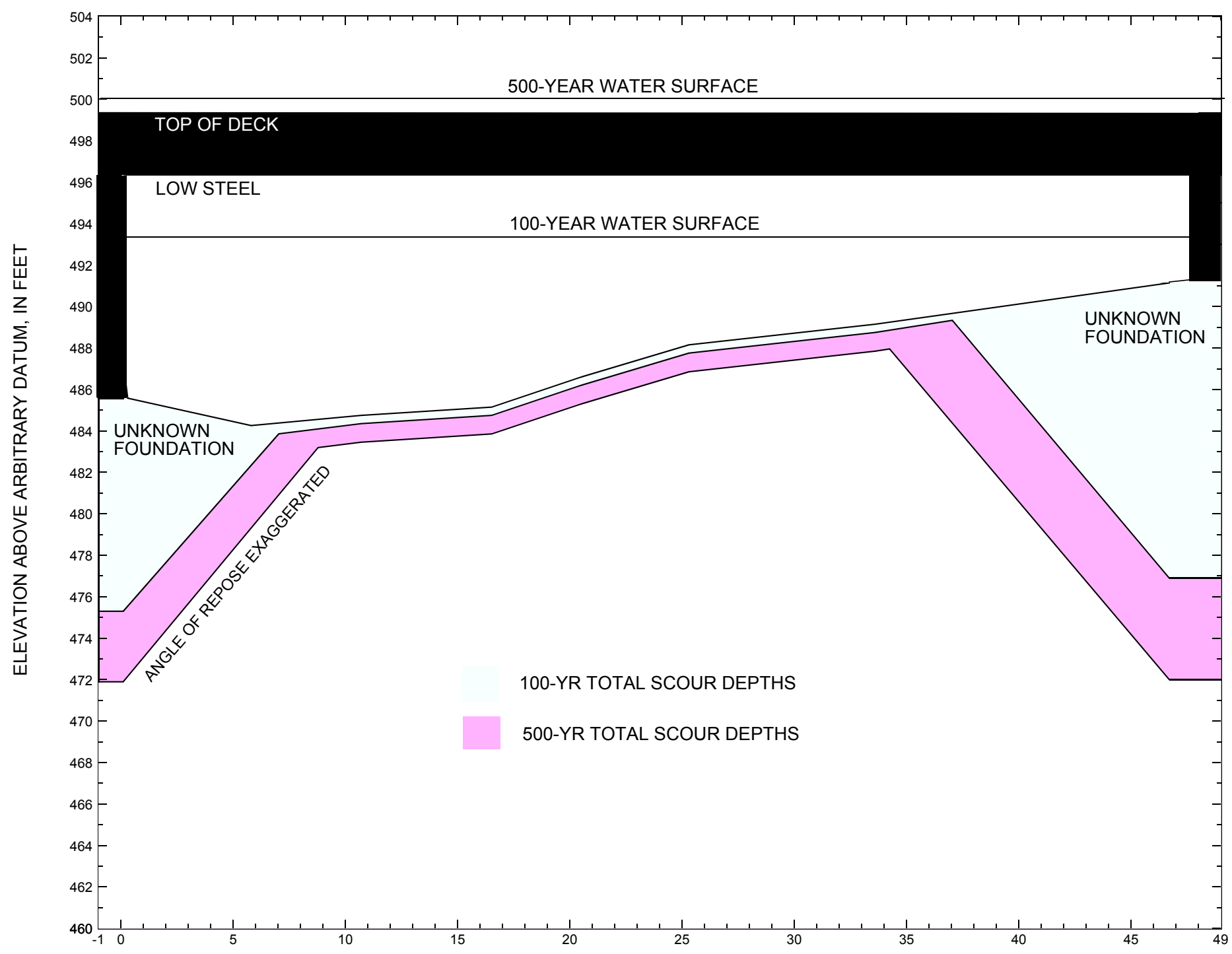

STATIONING FROM LEFT TO RIGHT ALONG BRIDGE SECTION, IN FEET

Figure 8. Scour elevations for the 100-yr and 500-yr discharges at structure JERITH00350031 on Town Highway 35, crossing Mill Brook, Jericho, Vermont. 


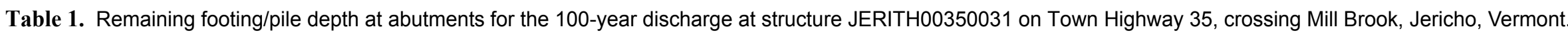
[VTAOT, Vermont Agency of Transportation; --,no data]

\begin{tabular}{|c|c|c|c|c|c|c|c|c|c|c|c|}
\hline Description & Station $^{1}$ & $\begin{array}{l}\text { VTAOT } \\
\text { minimum } \\
\text { low-chord } \\
\text { elevation } \\
\text { (feet) }\end{array}$ & $\begin{array}{l}\text { Surveyed } \\
\text { minimum } \\
\text { low-chord } \\
\text { elevation } \\
\text { (feet) }\end{array}$ & $\begin{array}{c}\text { Bottom of } \\
\text { footing } \\
\text { elevation } \\
\text { (feet) }\end{array}$ & $\begin{array}{c}\text { Channel } \\
\text { elevation at } \\
\text { abutment/ } \\
\text { pier }^{2} \\
\text { (feet) }\end{array}$ & $\begin{array}{l}\text { Contraction } \\
\text { scour depth } \\
\text { (feet) }\end{array}$ & $\begin{array}{l}\text { Abutment } \\
\text { scour } \\
\text { depth } \\
\text { (feet) }\end{array}$ & $\begin{array}{l}\text { Pier } \\
\text { scour } \\
\text { depth } \\
\text { (feet) }\end{array}$ & $\begin{array}{l}\text { Depth of } \\
\text { total scour } \\
\text { (feet) }\end{array}$ & $\begin{array}{c}\text { Elevation of } \\
\text { scour }^{2} \\
\text { (feet) }\end{array}$ & $\begin{array}{c}\text { Remaining } \\
\text { footing/pile } \\
\text { depth } \\
\text { (feet) }\end{array}$ \\
\hline \multicolumn{12}{|c|}{100 -yr. discharge is 3,300 cubic-feet per second } \\
\hline Left abutment & 0.0 & 334.9 & 496.4 & -- & 485.6 & 0.4 & 9.9 & -- & 10.3 & 475.3 & -- \\
\hline Right abutment & 48.0 & 334.9 & 496.4 & -- & 491.1 & 0.4 & 13.8 & -- & 14.2 & 476.9 & -- \\
\hline
\end{tabular}

1.Measured along the face of the most constricting side of the bridge.

2.Arbitrary datum for this study.

Table 2. Remaining footing/pile depth at abutments for the 500-year discharge at structure JERITH00350031 on Town Highway 35, crossing Mill Brook, Jericho, Vermont. [VTAOT, Vermont Agency of Transportation; --, no data]

\begin{tabular}{|c|c|c|c|c|c|c|c|c|c|c|c|}
\hline Description & Station $^{1}$ & $\begin{array}{l}\text { VTAOT } \\
\text { minimum } \\
\text { low-chord } \\
\text { elevation } \\
\text { (feet) }\end{array}$ & $\begin{array}{l}\text { Surveyed } \\
\text { minimum } \\
\text { low-chord } \\
\text { elevation } \\
\text { (feet) }\end{array}$ & $\begin{array}{c}\text { Bottom of } \\
\text { footing } \\
\text { elevation } \\
\text { (feet) }\end{array}$ & $\begin{array}{c}\text { Channel } \\
\text { elevation at } \\
\text { abutment/ } \\
\text { pier }^{2} \\
\text { (feet) }\end{array}$ & $\begin{array}{l}\text { Contraction } \\
\text { scour depth } \\
\text { (feet) }\end{array}$ & $\begin{array}{l}\text { Abutment } \\
\text { scour } \\
\text { depth } \\
\text { (feet) }\end{array}$ & $\begin{array}{l}\text { Pier } \\
\text { scour } \\
\text { depth } \\
\text { (feet) }\end{array}$ & $\begin{array}{l}\text { Depth of } \\
\text { total scour } \\
\text { (feet) }\end{array}$ & $\begin{array}{c}\text { Elevation of } \\
\text { scour }^{2} \\
\text { (feet) }\end{array}$ & $\begin{array}{c}\text { Remaining } \\
\text { footing/pile } \\
\text { depth } \\
\text { (feet) }\end{array}$ \\
\hline \multicolumn{12}{|c|}{500 -yr. discharge is 4,750 cubic-feet per second } \\
\hline Left abutment & 0.0 & 334.9 & 496.4 & -- & 485.6 & 1.3 & 12.4 & -- & 13.7 & 471.9 & -- \\
\hline Right abutment & 48.0 & 334.9 & 496.4 & -- & 491.1 & 1.3 & 17.8 & -- & 19.1 & 472.0 & -- \\
\hline
\end{tabular}

1.Measured along the face of the most constricting side of the bridge.

2.Arbitrary datum for this study. 


\section{SELECTED REFERENCES}

Arcement, G.J., Jr., and Schneider, V.R., 1989, Guide for selecting Manning's roughness coefficients for natural channels and flood plains: U.S. Geological Survey Water-Supply Paper 2339, 38 p.

Barnes, H.H., Jr., 1967, Roughness characteristics of natural channels: U.S. Geological Survey Water-Supply Paper 1849, 213 p.

Benson, M. A., 1962, Factors Influencing the Occurrence of Floods in a Humid Region of Diverse Terrain: U.S. Geological Survey Water-Supply Paper 1580-B, 64 p.

Brown, S.A. and Clyde, E.S., 1989, Design of riprap revetment: Federal Highway Administration Hydraulic Engineering Circular No. 11, Publication FHWA-IP-89-016, 156 p.

Federal Highway Administration, 1983, Runoff estimates for small watersheds and development of sound design: Federal Highway Administration Report FHWA-RD-77-158.

Federal Highway Administration, 1993, Stream Stability and Scour at Highway Bridges: Participant Workbook: Federal Highway Administration Report FHWA-HI-91-011.

Froehlich, D.C., 1989, Local scour at bridge abutments in Ports, M.A., ed., Hydraulic Engineering--Proceedings of the 1989 National Conference on Hydraulic Engineering: New York, American Society of Civil Engineers, p. 13-18.

Hayes, D.C.,1993, Site selection and collection of bridge-scour data in Delaware, Maryland, and Virginia: U.S. Geological Survey Water-Resources Investigation Report 93-4017, 23 p.

Interagency Advisory Committee on Water Data, 1982, Guidelines for determining flood flow frequency: U.S. Geological Survey, Bulletin 17B of the Hydrology Subcommittee, 190 p.

Johnson, C.G. and Tasker, G.D.,1974, Progress report on flood magnitude and frequency of Vermont streams: U.S. Geological Survey Open-File Report 74-130, 37 p.

Lagasse, P.F., Schall, J.D., Johnson, F., Richardson, E.V., Chang, F., 1995, Stream Stability at Highway Structures: Federal Highway Administration Hydraulic Engineering Circular No. 20, Publication FHWA-IP-90-014, 144 p.

Laursen, E.M., 1960, Scour at bridge crossings: Journal of the Hydraulics Division, American Society of Civil Engineers, v. 86, no. HY2, p. 39-53.

Potter, W. D., 1957a, Peak rates of runoff in the Adirondack, White Mountains, and Maine woods area, Bureau of Public Roads

Potter, W. D., 1957b, Peak rates of runoff in the New England Hill and Lowland area, Bureau of Public Roads

Richardson, E.V. and Davis, S.R., 1995, Evaluating scour at bridges: Federal Highway Administration Hydraulic Engineering Circular No. 18, Publication FHWA-IP-90-017, 204 p.

Richardson, E.V., Simons, D.B., and Julien, P.Y., 1990, Highways in the river environment: Federal Highway Administration Publication FHWAHI-90-016.

Ritter, D.F., 1984, Process Geomorphology: W.C. Brown Co., Debuque, Iowa, 603 p.

Shearman, J.O., 1990, User's manual for WSPRO--a computer model for water surface profile computations: Federal Highway Administration Publication FHWA-IP-89-027, 187 p.

Shearman, J.O., Kirby, W.H., Schneider, V.R., and Flippo, H.N., 1986, Bridge waterways analysis model; research report: Federal Highway Administration Publication FHWA-RD-86-108, 112 p.

Talbot, A.N., 1887, The determination of water-way for bridges and culverts.

U.S. Department of Transportation, 1993, Stream stability and scour at highway bridges, Participant Workbook: Federal Highway Administration Publication FHWA HI-91-011.

U.S. Geological Survey, 1948, Essex Junction, Vermont 7.5 Minute Series quadrangle map: U.S. Geological Survey Topographic Maps, Photoinspected 1987, Scale 1:24,000. 


\section{APPENDIX A: \\ WSPRO INPUT FILE}




\section{WSPRO INPUT FILE}

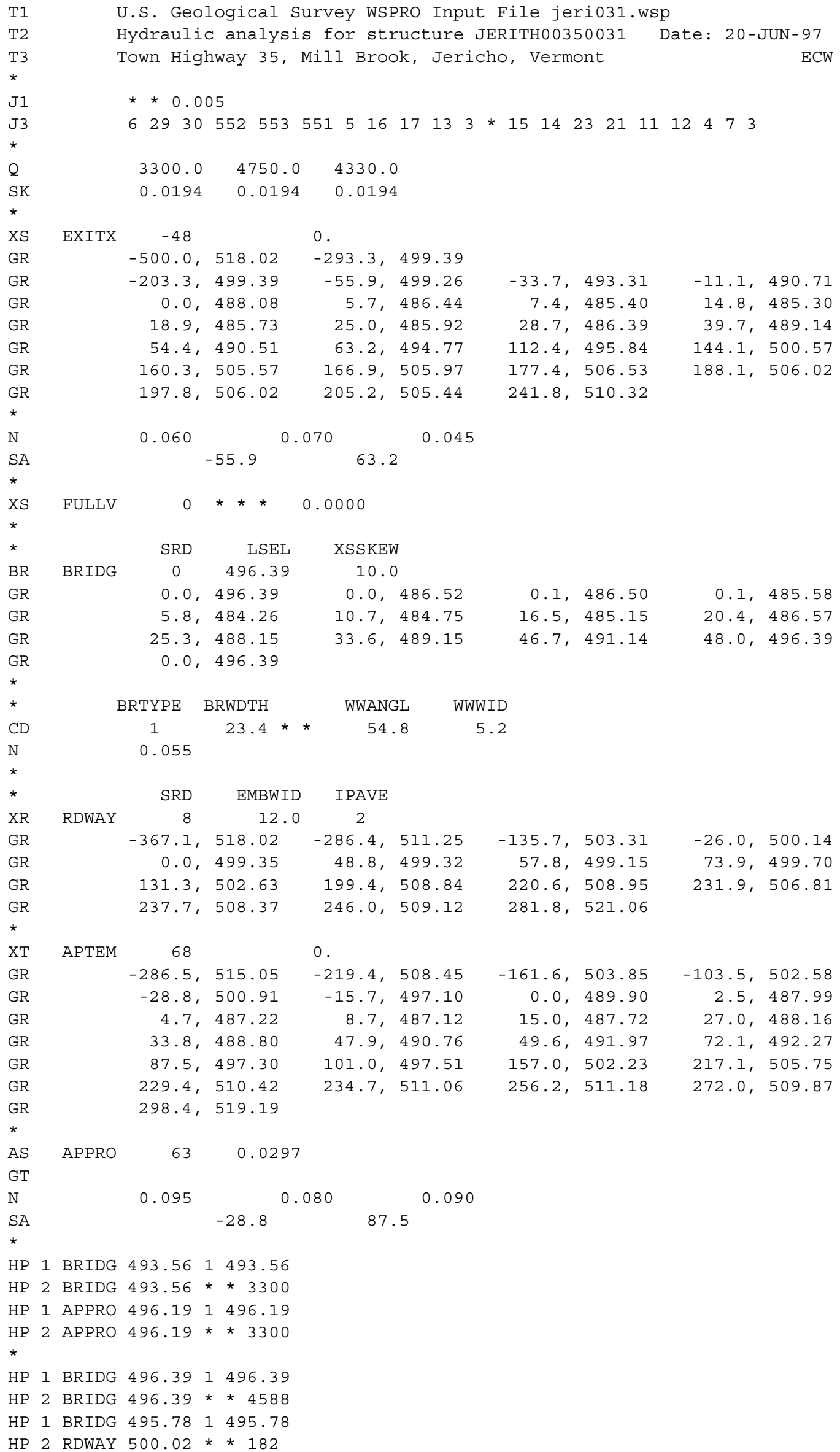




\section{APPENDIX B: \\ WSPRO OUTPUT FILE}




\section{WSPRO OUTPUT FILE}

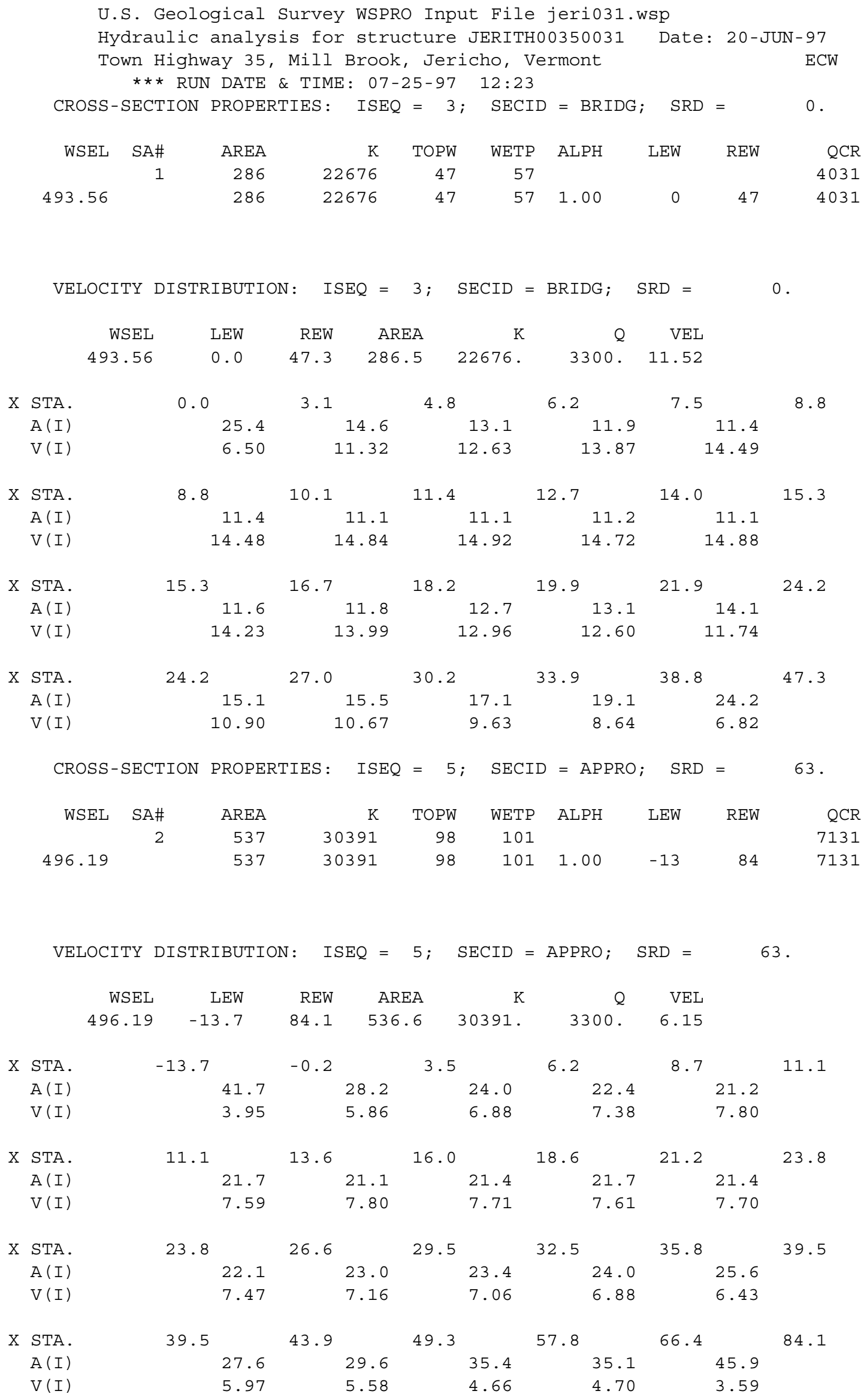




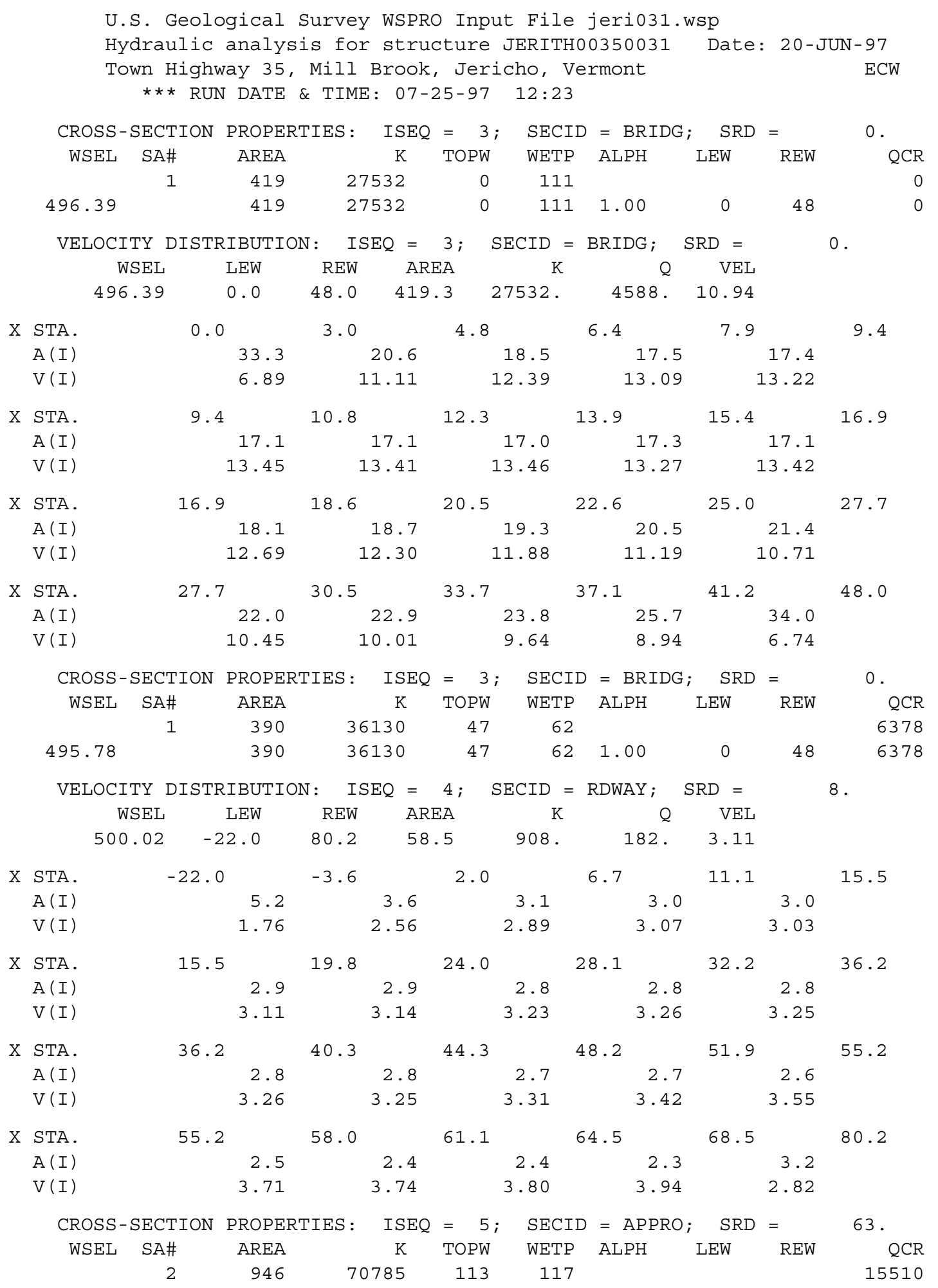




\section{WSPRO OUTPUT FILE (continued)}

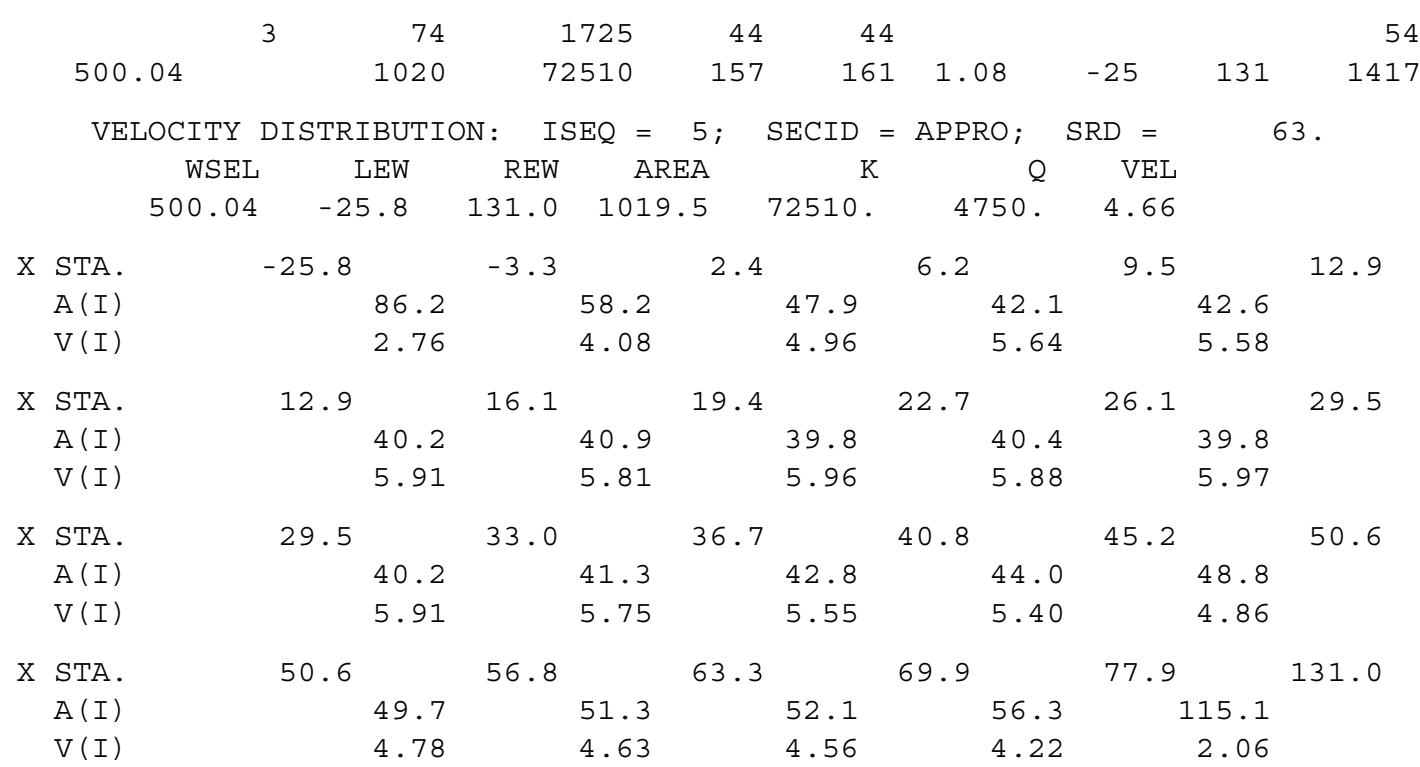

U.S. Geological Survey WSPRO Input File jerio31.wsp

Hydraulic analysis for structure JERITH00350031 Date: 20-JUN-97 Town Highway 35, Mill Brook, Jericho, Vermont ECW *** RUN DATE \& TIME: 07-25-97 12:23

CROSS-SECTION PROPERTIES: ISEQ = 3; SECID = BRIDG; $\quad$ SRD $=\quad 0$. WSEL SA\# AREA K TOPW WETP ALPH LEW REW $\begin{array}{lllllllll}496.39 & 1 & 419 & 27532 & 0 & 111 & & & \\ 496 & 419 & 27532 & 0 & 111 & 1.00 & 0 & 48 & 0\end{array}$

VELOCITY DISTRIBUTION : ISEQ = 3; SECID = BRIDG; $\quad$ SRD $=\quad 0$. $\begin{array}{rrrrrrr}\text { WSEL } & \text { LEW } & \text { REW } & \text { AREA } & \text { K } & \text { Q } & \text { VEL } \\ 496.39 & 0.0 & 48.0 & 419.3 & 27532 . & 4330 . & 10.33\end{array}$

\begin{tabular}{|c|c|c|c|c|c|c|c|c|c|c|c|c|}
\hline $\mathrm{X}$ & STA. & 0.0 & & 3.0 & & 4 & .8 & & 6.4 & 7.9 & & 9.4 \\
\hline & $A(I)$ & & 33.3 & & 20.6 & & & 3.5 & 17.5 & & 17.4 & \\
\hline & $V(I)$ & & 6.50 & & 10.49 & & & 69 & 12.36 & & 12.48 & \\
\hline $\mathrm{X}$ & STA. & 9.4 & & 10.8 & & 12 & & & 3.9 & 15.4 & & 16.9 \\
\hline & $A(I)$ & & 17.1 & & 17.1 & & & 7.0 & 17.3 & & 17.1 & \\
\hline & $V(I)$ & & 12.70 & & 12.65 & & & 70 & 12.52 & & 12.66 & \\
\hline $\mathrm{X}$ & STA. & 16.9 & & 18.6 & & 20 & & & 2.6 & 25.0 & & 27.7 \\
\hline & $A(I)$ & & 18.1 & & 18.7 & & & 9.3 & 20.5 & & 21.4 & \\
\hline & $V(I)$ & & 11.98 & & 11.61 & & & 21 & 10.56 & & 10.10 & \\
\hline $\mathrm{X}$ & STA. & 27.7 & & 30.5 & & 33 & & & 7.1 & 41.2 & & 48.0 \\
\hline & $A(I)$ & & 22.0 & & 22.9 & & & 3.8 & 25.7 & & 34.0 & \\
\hline & $V(I)$ & & 9.86 & & 9.45 & & & 09 & 8.44 & & 6.36 & \\
\hline & CROSS - & SECTION & PROPERT & ГIES : & ISEQ & $=$ & $3 ;$ & SECID & $=\mathrm{BRIDG}$ & SRD & $=$ & 0. \\
\hline & WSEL & SA\# & AREA & & $\mathrm{K}$ & $\mathrm{TOI}$ & PW & WETP & ALPH & LEW & REW & QCR \\
\hline & & 1 & 374 & & 3822 & & 47 & 61 & & & & 5973 \\
\hline & 495.42 & & 374 & & 3822 & & 47 & 61 & 1.00 & 0 & 48 & 5973 \\
\hline & CROSS - & SECTION & PROPERT & IIES : & ISEQ & $=$ & $5 ;$ & SECID & $=\mathrm{APPRO}$ & SRD & $=$ & 63. \\
\hline & WSEL & SA\# & AREA & & K & $\mathrm{TOI}$ & $\mathrm{PW}$ & WETP & $\mathrm{ALPH}$ & LEW & REW & QCR \\
\hline
\end{tabular}




\section{WSPRO OUTPUT FILE (continued)}

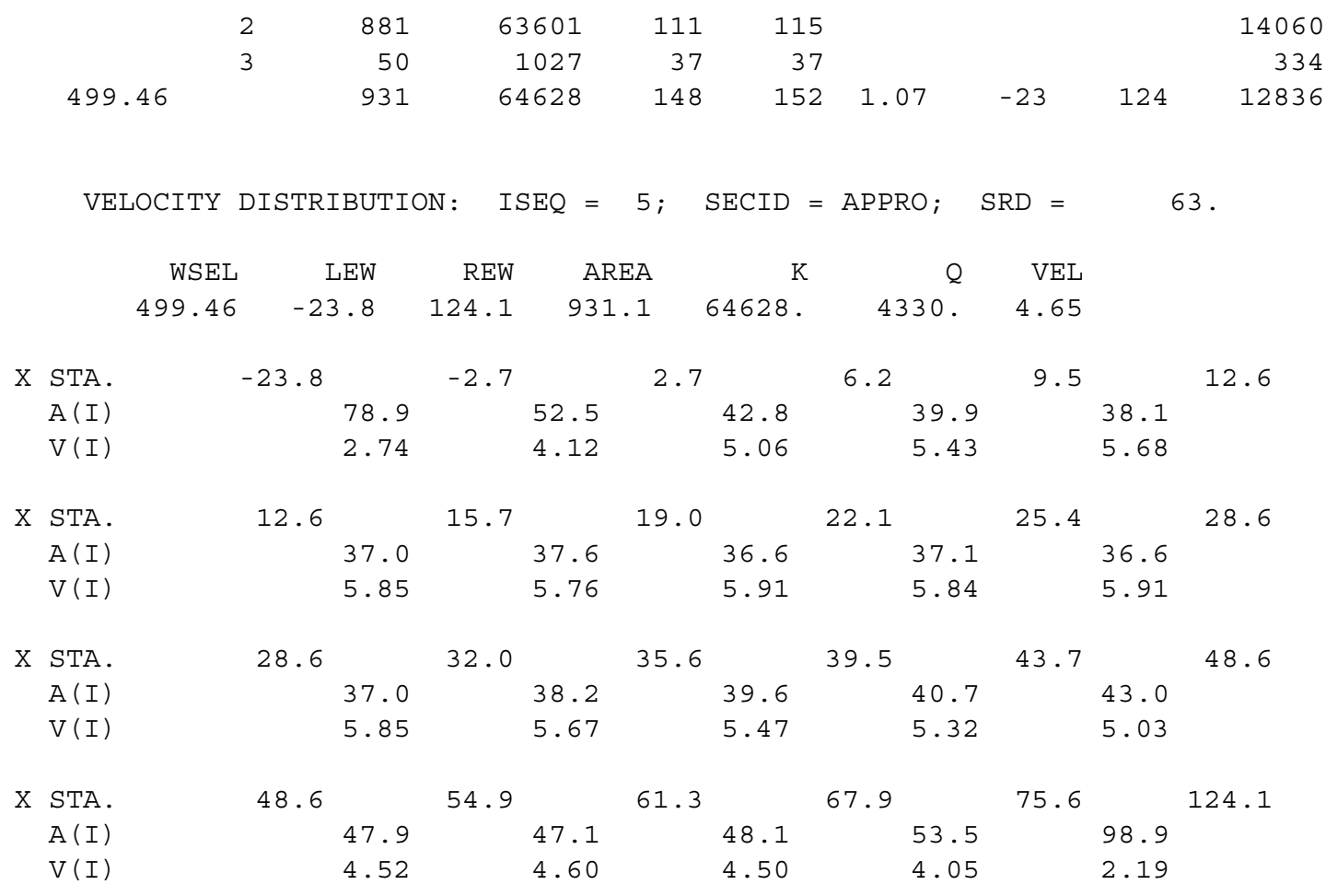

\footnotetext{
U.S. Geological Survey WSPRO Input File jeri031.wsp Hydraulic analysis for structure JERITH00350031 Date: 20-JUN-97 Town Highway 35, Mill Brook, Jericho, Vermont ECW *** RUN DATE \& TIME: 07-25-97 12:23

\begin{tabular}{|c|c|c|c|c|c|c|c|c|c|}
\hline XSID : CODE & SRDL & LEW & AREA & VHD & $\mathrm{HF}$ & EGL & CRWS & $Q$ & WSEL \\
\hline SRD & FLEN & REW & $\mathrm{K}$ & ALPH & $\mathrm{HO}$ & ERR & FR\# & VEL & \\
\hline ITX:XS & 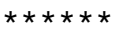 & -33 & 419 & 0.96 & $\star * \star * *$ & 494.44 & 492.15 & 3300 & 493.48 \\
\hline-47 & 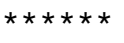 & 61 & 23692 & 1.00 & $\star \star \star \star *$ & 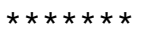 & 0.66 & 7.87 & \\
\hline LLV : FV & 48 & -37 & 518 & 0.63 & 0.68 & 495.12 & $\star \star \star \star \star \star \star \star *$ & 3300 & 494.49 \\
\hline 0 & 48 & 63 & 32315 & 1.00 & 0.00 & -0.01 & 0.50 & 6.37 & \\
\hline
\end{tabular}

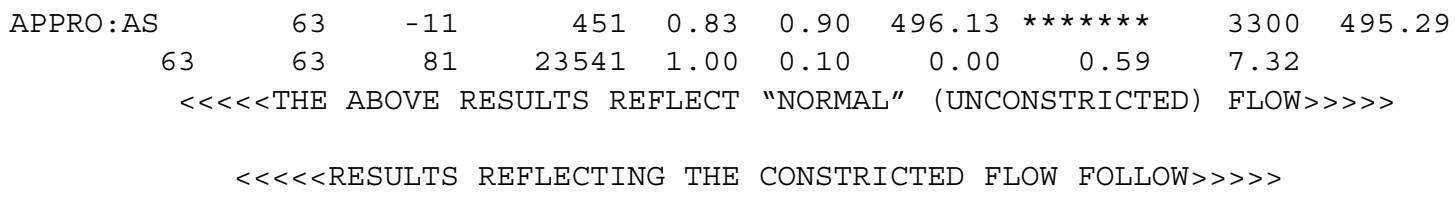




\section{WSPRO OUTPUT FILE (continued)}

U.S. Geological Survey WSPRO Input File jerio31.wsp Hydraulic analysis for structure JERITH00350031 Date: 20-JUN-97 Town Highway 35, Mill Brook, Jericho, Vermont ECW *** RUN DATE \& TIME: 07-25-97 12:23

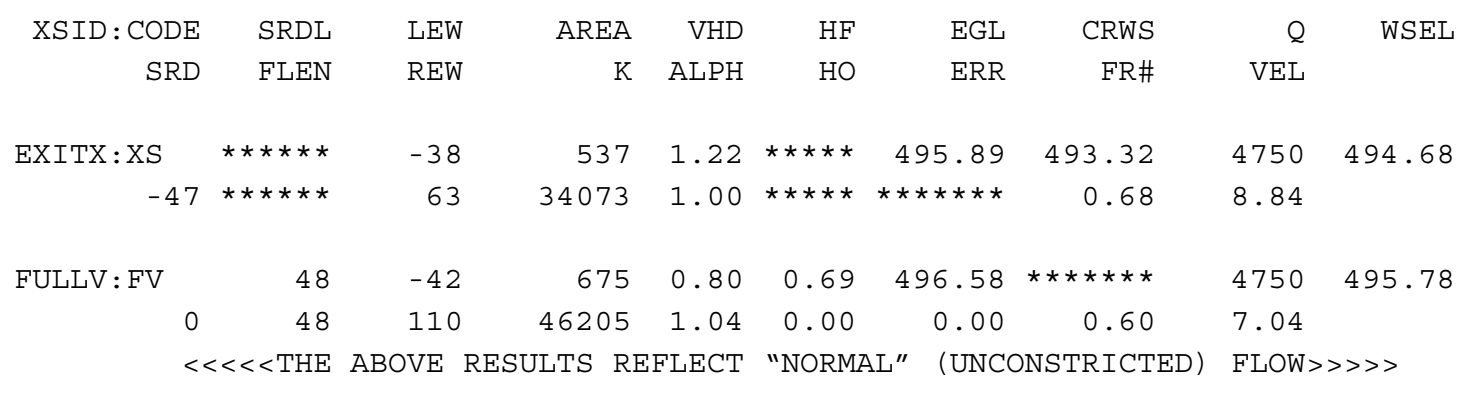

$\begin{array}{rrrrrrrrrr}\text { APPRO }: \text { AS } & 63 & -14 & 574 & 1.07 & 0.92 & 497.63 & * * * * * * * & 4750 & 496.56 \\ 63 & 63 & 85 & 33498 & 1.00 & 0.13 & 0.00 & 0.61 & 8.28 \\ & <<<<\text { THE } & \text { ABOVE RESULTS REFLECT } & \text { "NORMAL" } & \text { (UNCONSTRICTED) } & \text { FLOW }>>>>~\end{array}$

$==220$ FLOW CLASS 1 (4) SOLUTION INDICATES POSSIBLE PRESSURE FLOW . WS3, WSIU, WS1, LSEL $=494.29 \quad 497.87 \quad 498.54 \quad 496.39$ $==245$ ATTEMPTING FLOW CLASS 2 (5) SOLUTION.

$<<<<$ RESULTS REFLECTING THE CONSTRICTED FLOW FOLLOW $>>>>>$

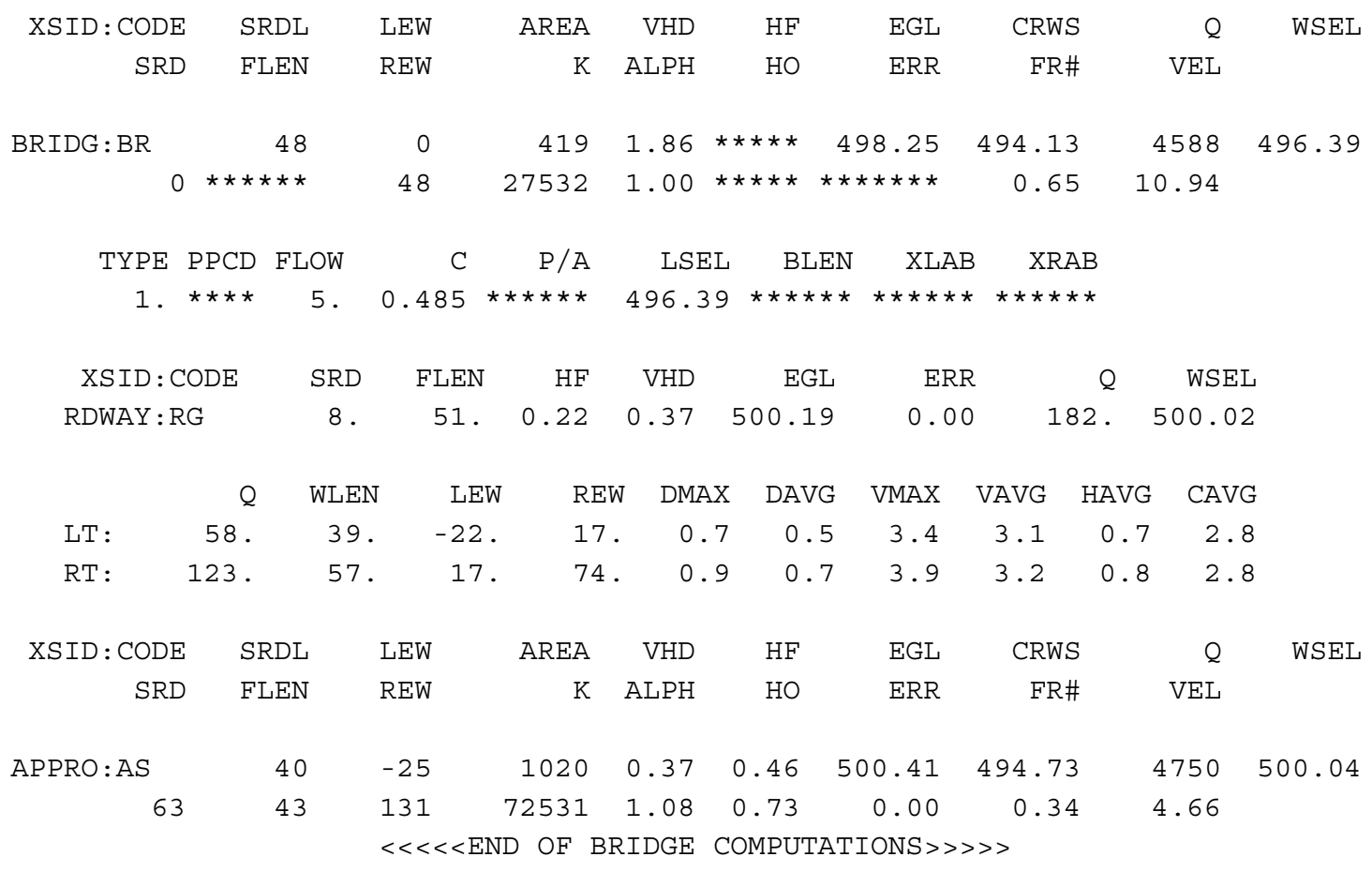
FIRST USER DEFINED TABLE.

$\begin{array}{lrrrrrrrr}\text { XSID }: \text { CODE } & \text { SRD } & \text { LEW } & \text { REW } & Q & \text { K } & \text { AREA } & \text { VEL } & \text { WSEL } \\ \text { EXITX }: \text { XS } & -48 . & -39 . & 63 . & 4750 . & 34073 . & 537 . & 8.84 & 494.68 \\ \text { FULLV }: \text { FV } & 0 . & -43 . & 110 . & 4750 . & 46205 . & 675 . & 7.04 & 495.78 \\ \text { BRIDG }: \text { BR } & 0 . & 0 . & 48 . & 4588 . & 27532 . & 419 . & 10.94 & 496.39 \\ \text { RDWAY }: \text { RG } & 8 . * * * * * * & 58 . & 182 . & 0 . & 0 . & 2.00 & 500.02 \\ \text { APPRO }: \text { AS } & 63 . & -26 . & 131 . & 4750 . & 72531 . & 1020 . & 4.66 & 500.04\end{array}$

SECOND USER DEFINED TABLE. 


\section{WSPRO OUTPUT FILE (continued)}

U.S. Geological Survey WSPRO Input File jerio31.wsp Hydraulic analysis for structure JERITH00350031 Date: 20-JUN-97 Town Highway 35, Mill Brook, Jericho, Vermont ECW *** RUN DATE \& TIME: 07-25-97 12:23

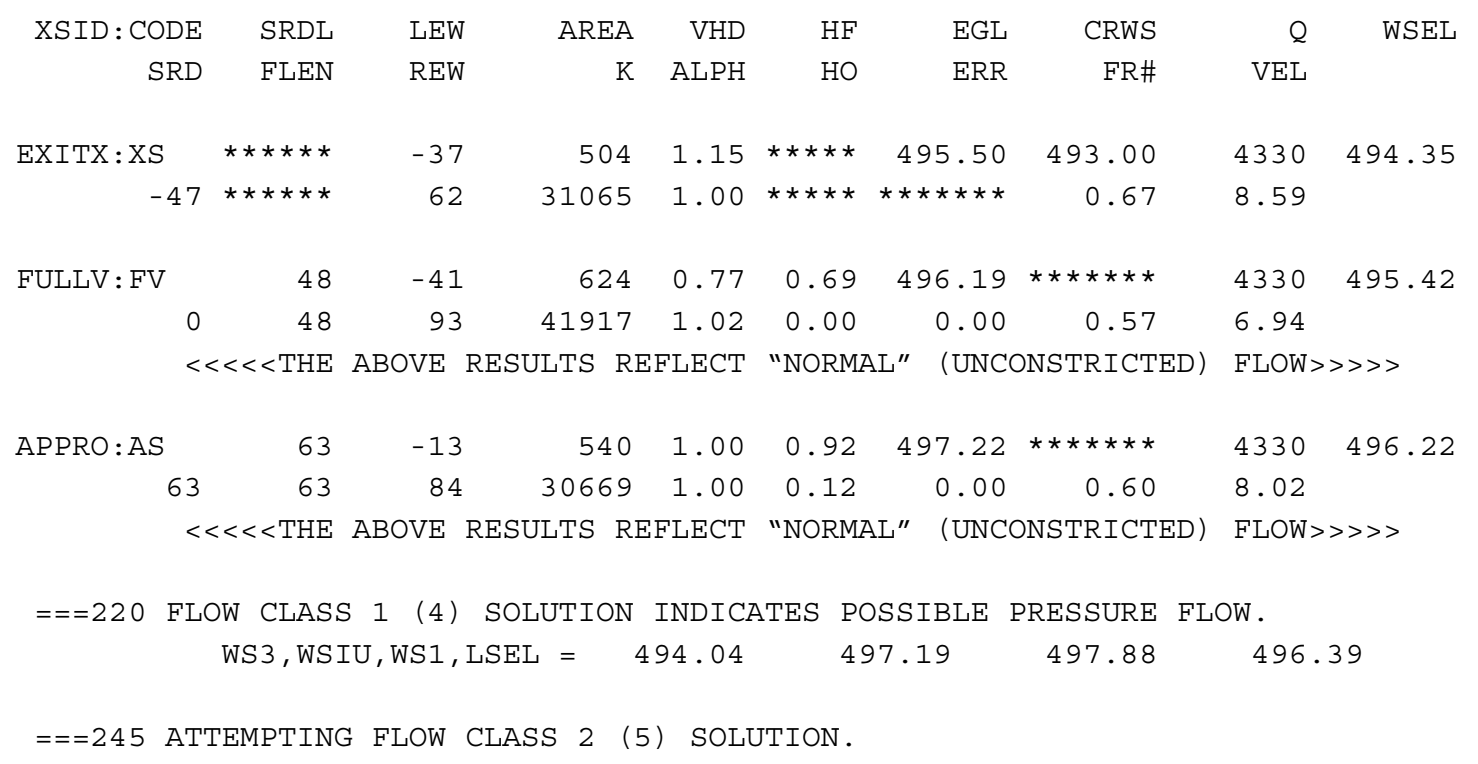
$<<<<$ RESULTS REFLECTING THE CONSTRICTED FLOW FOLLOW $>>>>>$

\begin{tabular}{|c|c|c|c|c|c|c|c|c|c|c|}
\hline \multirow{2}{*}{$\begin{array}{r}\text { XSID : CODE } \\
\text { SRD }\end{array}$} & \multicolumn{2}{|c|}{ SRDL } & LEW & AREA & VHD & $\mathrm{HF}$ & EGL & CRWS & $Q$ & WSEL \\
\hline & \multicolumn{2}{|c|}{ FLEN } & REW & K & $\mathrm{ALPH}$ & $\mathrm{HO}$ & $\mathrm{ERR}$ & FR\# & VEL & \\
\hline \multirow[t]{2}{*}{ BRIDG : BR } & \multirow{2}{*}{\multicolumn{2}{|c|}{$\begin{array}{r}48 \\
\star \star \star \star \star \star\end{array}$}} & 0 & 419 & 1.66 * & $\star * \star * *$ & 498.05 & 493.87 & 4331 & 496.39 \\
\hline & & & 48 & 27532 & $1.00 *$ & $\star * \star * *$ & $\star \star * \star * \star * *$ & 0.62 & 10.33 & \\
\hline TYPE P & PPCD & FLOW & C & $\mathrm{P} / \mathrm{A}$ & LSEL & BLEN & XLAB & XRAB & & \\
\hline 1. * & $* * * *$ & 2 . & 0.475 & $\star \star \star \star \star \star * \star$ & 496.39 & $9 * \star * *$ & $* * \quad * * * * *$ & $\star \star \star \star \star \star * \star *$ & & \\
\hline $\mathrm{XSID}: \mathrm{CO}$ & DDE & SRD & FLEN & $\mathrm{HF}$ & VHD & $\mathrm{EG}$ & $\mathrm{ERI}$ & . & WSEL & \\
\hline RDWAY : RG & & 8 . & & $<<<<<$ EI & MBANKME & ENT IS & NOT OVE & RTOPPED>> & $>>>$ & \\
\hline XSID: CODE & & RDL & LEW & AREA & VHD & $\mathrm{HF}$ & EGL & CRWS & Q & WSEL \\
\hline SRD & & LEN & REW & K & $\mathrm{ALPH}$ & $\mathrm{HO}$ & $\mathrm{ERR}$ & FR\# & VEL & \\
\hline APPRO : AS & & 40 & -23 & 932 & 0.36 & 0.45 & 499.82 & 494.44 & 4330 & 499.46 \\
\hline 63 & & 42 & 124 & 64663 & 1.07 & 0.68 & 0.00 & 0.34 & 4.65 & \\
\hline $\mathrm{M}(\mathrm{G})$ & & $\mathrm{M}(\mathrm{K})$ & $\mathrm{KQ}$ & XLKQ & XRKQ & & TEL & & & \\
\hline 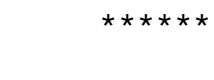 & $\star \star \star * *$ & $\star \star \star \star$ & $\begin{array}{c}* \star * \star * \star * \\
\quad<<<<\text { EI }\end{array}$ & $\begin{array}{l}* * * * * * \\
\text { ND OF BF }\end{array}$ & $\begin{array}{l}* \star * * * * \\
\text { RIDGE C }\end{array}$ & $\begin{array}{r}49 \\
\text { COMPUT }\end{array}$ & $\begin{array}{l}9.23 \\
\text { ATION }\end{array}$ & & & \\
\hline
\end{tabular}
FIRST USER DEFINED TABLE.

$\begin{array}{lrrrrrrrr}\text { XSID : CODE } & \text { SRD } & \text { LEW } & \text { REW } & Q & \text { K } & \text { AREA } & \text { VEL } & \text { WSEL } \\ \text { EXITX }: X S & -48 . & -38 . & 62 . & 4330 . & 31065 . & 504 . & 8.59 & 494.35 \\ \text { FULLV : FV } & 0 . & -42 . & 93 . & 4330 . & 41917 . & 624 . & 6.94 & 495.42 \\ \text { BRIDG : BR } & 0 . & 0 . & 48 . & 4331 . & 27532 . & 419 . & 10.33 & 496.39 \\ \text { RDWAY : RG } & 8 . * * * * * * * * * * * * * & 0 . & 0 . & 0 . & 2.00 * * * * * * * \\ \text { APPRO : AS } & 63 . & -24 . & 124 . & 4330 . & 64663 . & 932 . & 4.65 & 499.46\end{array}$

SECOND USER DEFINED TABLE. 


\section{APPENDIX C:}

\section{BED-MATERIAL PARTICLE-SIZE DISTRIBUTION}




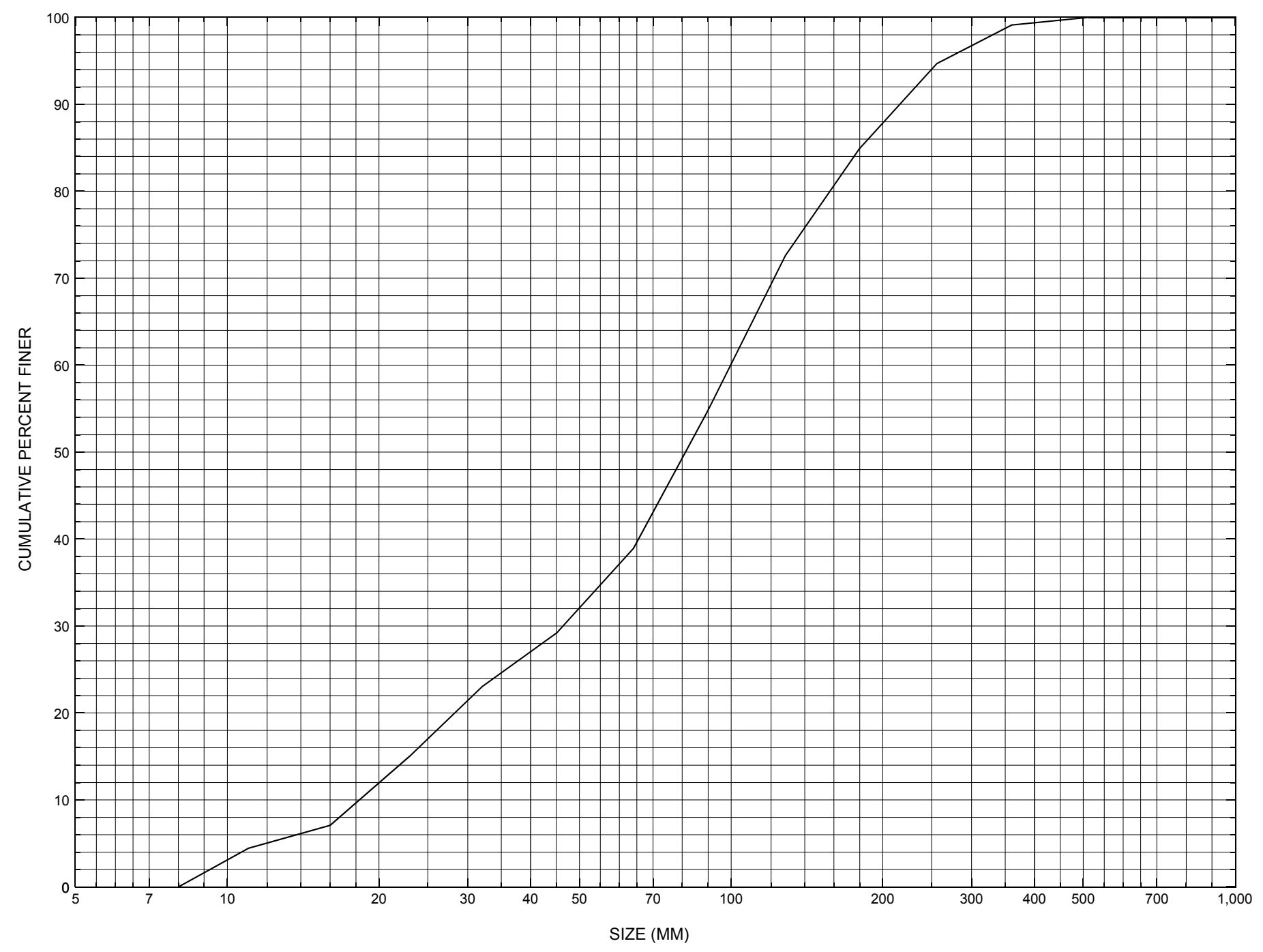

Appendix C. Bed material particle-size distribution for a pebble count in the channel approach of structure JERITH00350031, in Jericho, Vermont. 


\section{APPENDIX D: \\ HISTORICAL DATA FORM}




\section{Structure Number JERITH00350031}

\section{General Location Descriptive}

Data collected by (First Initial, Full last name) $\underline{\mathbf{L}}$. Medalie

Date $(M M / D D / Y Y) \_\mathbf{1 1} / \underline{30} / \underline{95}$

Highway District Number (I - 2; nn) $\mathbf{0 5}$

Town (FIPS place code; I - 4; nnnnn) $\mathbf{3 6 7 0 0}$

Waterway (I - 6) MILL BROOK

Route Number $\mathbf{C 3 0 3 5}$

Topographic Map Essex.Junction

Latitude (I - 16; nnnn.n) $\mathbf{4 4 2 7 4}$
County (FIPS county code; I - 3; nnn)

Mile marker (I - 11; nnn.nnn) $\mathbf{0 0 0 0 0 0}$

Road Name (I - 7): TARBOX ROAD

Vicinity (I - 9) 0.04 MI TO JCT W CL2 TH1

Hydrologic Unit Code: -

Longitude (i - 17; nnnnn.n) 73008

\section{Select Federal Inventory Codes}

FHWA Structure Number $(I-8) \quad \mathbf{1 0 0 4 0 9 0 0 3 1 0 4 0 9}$

Maintenance responsibility $(I-21 ; n n) \quad \mathbf{0 3} \quad$ Maximum span length $(I-48 ; n n n n) \underline{\mathbf{0 0 5 0}}$

Year built (I - 27; YYYY) 1919

Structure length (I - 49; nnnnnn) $\underline{\mathbf{0 0 0 0 5 3}}$

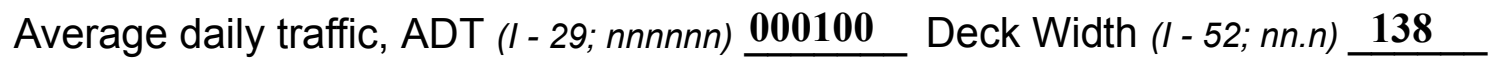

Year of ADT (I - 30; YY) $\mathbf{9 3}$

Channel \& Protection $(I-61 ; n) \underline{4}$

Opening skew to Roadway $(I-34 ; n n) \quad \mathbf{1 0}$

Waterway adequacy $(I-71 ; n) \underline{6}$

Operational status $(I-41 ; X) \quad \mathbf{B}$

Underwater Inspection Frequency $(I-92 B ; X Y Y) \_\mathbf{N}$

Structure type (I - 43; nnn) $\mathbf{3 0 3}$

Year Reconstructed (I - 106) $\mathbf{0 0 0 0}$

Approach span structure type $(I-44 ; n n n) \quad \mathbf{0 0 0}$

Clear span $(n n n . n f t) \quad \mathbf{4 9}$

Number of spans (I - 45; nnn) $\underline{\mathbf{0 0 1}}$

Vertical clearance from streambed (nnn.n ft) $\underline{11}$

Number of approach spans (I - 46; nnnn) $\underline{\mathbf{0 0 0 0}}$ Waterway of full opening $\left(n n n . n \mathrm{ft}^{2}\right) \underline{\mathbf{5 3 9}}$

Comments:

According to the structural inspection report dated 11/22/93, the structure is an I-beam side girder with a wooden deck. The RABUT and its wings are laid up stone with a concrete cap and backwall. The laid up stone has small voids overall. The backwall has a 2 " vertical crack just to the right of centerline with 6 " vertical cracks on both ends and some movement along the crack lines. The LABUT, wings, backwall, and footing are concrete. The abutment has fine cracks and small leaks overall with alligator cracks and leaks and some spalling on the wing ends. The backwall has a 1/4" diagonal crack near centerline. The abutment has a 6" wide footing, with a 12" wide footing on the left wing. The left half of the abutment is under-

(Continued on page 33) 


\section{Bridge Hydrologic Data}

Is there hydrologic data available? $\mathbf{Y}$ if No, type ctrl-n $h$

VTAOT Drainage area $\left(m i^{2}\right): \mathbf{1 5 . 1 5}$

Terrain character: Hilly, mixed to mountainous, wooded

Stream character \& type:

Streambed material: Sand and silt with some cobbles and boulders

Discharge Data (cfs): $\quad Q_{2.33} 725$

$$
\mathrm{Q}_{50} \mathbf{2 7 5 0}
$$

$\mathrm{Q}_{10} \frac{\mathbf{1 6 0 0}}{\mathbf{3 3 0 0}}$

$\mathrm{Q}_{25} \lcm{2200}$

$\mathrm{Q}_{500}$

Record flood date ( $M M / D D / Y Y$ ):

Water surface elevation (ft):

Estimated Discharge (cfs):

Velocity at $\mathrm{Q}$ $(\mathrm{ft} / \mathrm{s})$ :

Ice conditions (Heavy, Moderate, Light) :

Debris (Heavy, Moderate, Light):

The stage increases to maximum highwater elevation (Rapidly, Not rapidly):

The stream response is (Flashy, Not flashy):

Describe any significant site conditions upstream or downstream that may influence the stream's stage: According to a memo in the hydraulics files dated 7/11/95, a large sand, silt, and stone deposit sits adjacent to the right abutment. The river runs under the left portion of the bridge. $A$ portion of the DS end of the LABUT has undergone some mild scour. Approximate 4" of what appears to be the footing is exposed.

Watershed storage area (in percent): $\%$

The watershed storage area is: (1-mainly at the headwaters; 2- uniformly distributed; 3-immediatly upstream oi the site)

Water Surface Elevation Estimates for Existing Structure:

\begin{tabular}{|l|l|c|c|l|l|}
\hline Peak discharge frequency & $Q_{2.33}$ & $Q_{10}$ & $Q_{25}$ & $Q_{50}$ & $Q_{100}$ \\
Water surface elevation (ft)) & $\mathbf{3 2 8 . 9}$ & $\mathbf{3 3 1}$ & $\mathbf{3 3 2 . 5}$ & $\mathbf{3 3 3 . 6}$ & $\mathbf{3 3 4 . 6}$ \\
Velocity $(\mathrm{ft} / \mathrm{sec})$ & & & & & \\
\hline
\end{tabular}

Long term stream bed changes:

Is the roadway overtopped below the $Q_{100}$ ? (Yes, No, Unknown):

Frequency:

Relief Elevation ( $f t)$ :

Discharge over roadway at $Q_{100}\left(f t^{3} / \mathrm{sec}\right)$ :

Are there other structures nearby? (Yes, No, Unknown): $\mathbf{Y}$ Upstream distance (miles): 2 Town: Jericho If No or Unknown, type ctrl-n os

Highway No. : $\mathbf{T H 3 3}$ Structure No. : 32 Year Built:

Clear span (ft): $\mathbf{3 2 . 6}$ Clear Height $(f t): \underline{8}$

Full Waterway $\left(t^{2}\right):$ 
Downstream distance (miles): $\mathbf{. 3 8}$ Town: Jericho

Year Built:

Highway No. : SA-1 (VT117) Structure No. : 7

Structure Type: Comp. rolled

Clear span (ft): $\underline{\mathbf{6 1}}$ Clear Height $(f t): \underline{9}$

Full Waterway $\left(f^{2}\right): \mathbf{5 4 9}$

Comments:

mined at least 3-1/2' under by 8-12" deep, with small voided areas along the bottom of the left-wing footing. A homemade stone dam extends across the channel just downstream, raising the water level at least 1 to 1.5 '. A vegetation covered gravel bar in front of RABUT blocks nearly $2 / 3$ of the channel flow. Much of the channel flow is against the left end and left wing on the LABUT and a scour hole in the area has been partially filled in with boulder fill.

\section{USGS Watershed Data}

Watershed Hydrographic Data

Drainage area $(D A) \underline{15.74} \mathrm{mi}^{2}$ Lake and pond area $\mathbf{0 . 0 1}$ $\mathrm{mi}^{2}$

Watershed storage (ST)

Bridge site elevation 320 0.06 $\%$

Main channel length 10.56 $\mathrm{ft}$ Headwater elevation 3680 $\mathrm{ft}$ $10 \%$ channel length elevation $\mathbf{5 0 0}$ $\mathrm{ft} \quad 85 \%$ channel length elevation 1590 $\mathrm{ft}$

Main channel slope (S) $137.63 \mathrm{ft} / \mathrm{mi}$

Watershed Precipitation Data

Average site precipitation in Average headwater precipitation in

Maximum 2yr-24hr precipitation event $(124,2)$ in

Average seasonal snowfall (Sn) $\mathrm{ft}$ 


\section{Bridge Plan Data}

Are plans available? Yes If no, type ctrl-n pl Date issued for construction (MM/YYYY): Project Number BRO 1445 (22)

Minimum channel bed elevation: $\mathbf{3 2 2 . 7}$

Low superstructure elevation: USLAB DSLAB USRAB DSRAB Benchmark location description:

$-$

Reference Point (MSL, Arbitrary, Other): Arbitrary Datum (NAD27, NAD83, Other): Arbitrary Foundation Type: 4 (1-Spreadfooting; 2-Pile; 3- Gravity; 4-Unknown)

If 1: Footing Thickness _ _ Footing bottom elevation: -

If 2: Pile Type: ___ (1-Wood; 2-Steel or metal; 3-Concrete) Approximate pile driven length: -

If 3: Footing bottom elevation: -

Is boring information available? $\mathbf{N}$ If no, type ctrl-n bi Number of borings taken: -

Foundation Material Type: $\mathbf{3}$ (1-regolith, 2-bedrock, 3-unknown)

Briefly describe material at foundation bottom elevation or around piles:

$-$

Comments:

Bridge survey of 1995 profile plan state: low steel elevation of $334.9 \mathrm{ft}$ and top of bridge (roadway overflow) $337.9 \mathrm{ft}$. 


\section{Cross-sectional Data}

Is cross-sectional data available? $\mathbf{Y}$ If no, type ctrl-n xs

Source (FEMA, VTAOT, Other)? VTAOT

Comments: This cross section is the upstream face. The low cord elevation is from the hydraulic report Profile plot by the VT AOT on 7/11/95. The low cord to bed length data is from the sketch attached to bridge inspection report, dated 11/22/93.

\begin{tabular}{|l|l|l|l|l|l|l|l|l|l|l|l|}
\hline Station & LAB & & & & RAB & - & - & - & - & - & - \\
\hline Feature & $\mathbf{3 3 4 . 9}$ & $\mathbf{3 3 4 . 9}$ & $\mathbf{3 3 4 . 9}$ & $\mathbf{3 3 4 . 9}$ & $\mathbf{3 3 4 . 9}$ & - & - & - & - & - & - \\
\hline $\begin{array}{l}\text { Low cord } \\
\text { elevation }\end{array}$ & $\mathbf{3 2 2 . 7}$ & $\mathbf{3 2 2 . 7}$ & $\mathbf{3 2 5 . 9}$ & $\mathbf{3 2 7 . 5}$ & $\mathbf{3 2 6 . 4}$ & - & - & - & - & - & - \\
\hline $\begin{array}{l}\text { Bed } \\
\text { elevation }\end{array}$ & $\mathbf{1 2 . 2}$ & $\mathbf{1 2 . 2}$ & $\mathbf{9 . 0}$ & $\mathbf{7 . 4}$ & $\mathbf{6 . 3}$ & - & - & - & - & - & - \\
\hline $\begin{array}{l}\text { Low cord to } \\
\text { bed length }\end{array}$ & $\mathbf{1 1}$ & $\mathbf{2 2}$ & $\mathbf{3 7}$ & $\mathbf{4 9}$ & - & - & - & - & - & - & - \\
\hline Station & - & - & - & - & - & - & - & - & - & - & - \\
\hline Feature & - & - & - & - & - & - & - & - & - & - & - \\
\hline $\begin{array}{l}\text { Low cord } \\
\text { elevation }\end{array}$ & - & - & - & - & - & - & - & - & - & - & - \\
\hline $\begin{array}{l}\text { Bed } \\
\text { elevation }\end{array}$ & - & - & - & - & - & - & - & - & - & - & - \\
\hline $\begin{array}{l}\text { Low cord to } \\
\text { bed length }\end{array}$ & - & - & - & - & - & - & - & - & - & - & - \\
\hline
\end{tabular}

Source (FEMA, VTAOT, Other)?

Comments:

\begin{tabular}{|l|l|l|l|l|l|l|l|l|l|l|l|}
\hline Station & - & - & - & - & - & - & - & - & - & - & - \\
\hline Feature & - & - & - & - & - & - & - & - & - & - & - \\
\hline $\begin{array}{l}\text { Low cord } \\
\text { elevation }\end{array}$ & - & - & - & - & - & - & - & - & - & - & - \\
\hline $\begin{array}{l}\text { Bed } \\
\text { elevation }\end{array}$ & - & - & - & - & - & - & - & - & - & - & - \\
\hline $\begin{array}{l}\text { Low cord to } \\
\text { bed length }\end{array}$ & - & - & - & - & - & - & - & - & - & - & - \\
\hline Station & - & - & - & - & - & - & - & - & - & - & - \\
\hline Feature & - & - & - & - & - & - & - & - & - & - & - \\
\hline $\begin{array}{l}\text { Low cord } \\
\text { elevation }\end{array}$ & - & - & - & - & - & - & - & - & - & - & - \\
\hline $\begin{array}{l}\text { Bed } \\
\text { levation }\end{array}$ & - & - & - & - & - & - & - & - & - & - & - \\
\hline $\begin{array}{l}\text { Low cord to } \\
\text { bed length }\end{array}$ & - & - & - & - & - & - & - & - & - & - & - \\
\hline
\end{tabular}




\section{APPENDIX E: \\ LEVEL I DATA FORM}


U. S. Geological Survey

Bridge Field Data Collection and Processing Form

Qa/Qc Check by: EW Date: $\underline{\mathbf{0 8} / \mathbf{1 4} / 96}$

\section{Structure Number}

JERITH00350031 Date: $\underline{08 / 14 / 96}$ Computerized by: $\underline{\mathbf{E W}}$ Date: 08/06/97

\section{A. General Location Descriptive}

1. Data collected by (First Initial, Full last name) M. IVANOFF

2. Highway District Number $\mathbf{0 5}$

County_WASHINGTON 007

Mile marker $\mathbf{0 0 0 0 0 0}$

Waterway (I - 6) MILL BROOK

Route Number TH 35

Town JERICHO 36700

Road Name TAR BOX ROAD

Hydrologic Unit Code: $\mathbf{0 2 0 1 0 0 0 5}$

3. Descriptive comments:

Located 0.04 miles to junction with Town Highway 1.

\section{B. Bridge Deck Observations}
4. Surface cover... LBUS 6
RBUS 6
LBDS 4
RBDS 5
Overall 6

(2b us,ds,lb,rb: 1- Urban; 2- Suburban; 3- Row crops; 4- Pasture; 5- Shrub- and brushland; 6- Forest; 7- Wetland)
5. Ambient water surface... US 2
UB 1 DS 2
(1- pool; 2- riffle)

6. Bridge structure type 1 (1- single span; 2- multiple span; 3- single arch; 4- multiple arch; 5-cylindrical culvert; 6- box culvert; or 7- other)
7. Bridge length $\mathbf{5 3}$
(feet)
Span length $\underline{\mathbf{5 0}}$
(feet)
Bridge width 13.8 (feet)

\section{Road approach to bridge:}
8. LB 2
RB 2
( 0 even, 1- lower, 2- higher)
9. LB
RB $\underline{2}$
(1- Paved, 2- Not paved)

10. Embankment slope (run / rise in feet / foot)

US left

US right

\begin{tabular}{|c|c|c|c|}
\hline \multicolumn{2}{|c|}{ Protection } & \multirow{2}{*}{ 13.Erosion } & 14.Severity \\
\hline 11.Type & 12.Cond. & - & $\underline{\mathbf{1}}$ \\
\hline $\mathbf{0}$ & - & $\mathbf{0}$ & - \\
\hline $\mathbf{0}$ & - & - \\
$\mathbf{0}$ & - & $\mathbf{2}$ & $\mathbf{1}$ \\
\hline $\mathbf{2}$ & $\mathbf{1}$ & $\mathbf{0}$ & - \\
\hline
\end{tabular}

Bank protection types: 0- none; 1- < 12 inches;

2- < 36 inches; 3- < 48 inches;

4- < 60 inches; 5- wall / artificial levee

Bank protection conditions: 1- good; 2- slumped;

3- eroded; 4- failed

Erosion: 0 - none; 1- channel erosion; 2 -

road wash; 3- both; 4- other

Erosion Severity: 0 - none; 1- slight; 2- moderate; 3- severe

\section{Channel approach to bridge (BF):}

15. Angle of approach: $\mathbf{0}$

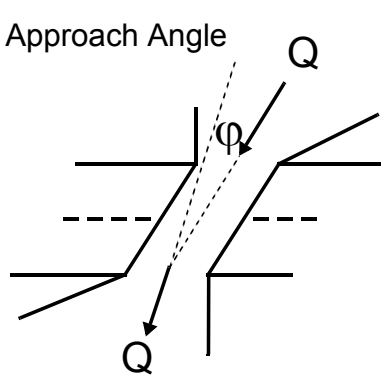

17. Channel impact zone 1 :

Where? LB (LB, RB)

Range? 35 feet US

Channel impact zone 2:

Where? $(L B, R B)$

Range? - $\quad$ feet -

(US, UB, DS) to feet Impact Severity: 0- none to very slight; 1- Slight; 2- Moderate; 3- Severe

16. Bridge skew: $\mathbf{0}$ Bridge Skew Angle

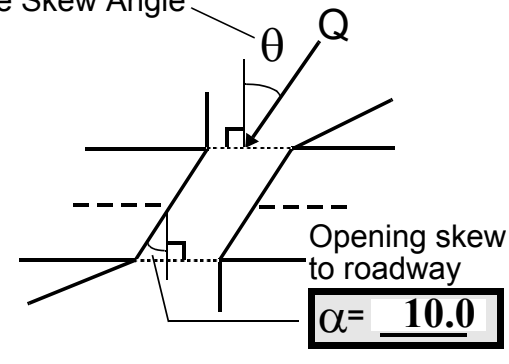

\section{Exist? $\mathbf{Y}(Y$ or $N)$}

Severity 1

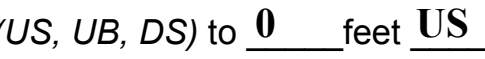

Exist? $\mathbf{N}(Y$ or $N)$

Severity - 
18. Bridge Type: 1a

1a- Vertical abutments with wingwalls

1 b- Vertical abutments without wingwalls

2- Vertical abutments and wingwalls, sloping embankment

Wingwalls perpendicular to abut. face

3- Spill through abutments

4- Sloping embankment, vertical wingwalls and abutments

Wingwall angle less than $90^{\circ}$.

19. Bridge Deck Comments (surface cover variations, measured bridge and span lengths, bridge type variations, approach overflow width, etc.)

\#7: Values from VTAOT database. Measured the following during site visit: bridge length is 54 feet; bridge span is 49 feet; and bridge width is 12 feet.

\section{Upstream Channel Assessment}

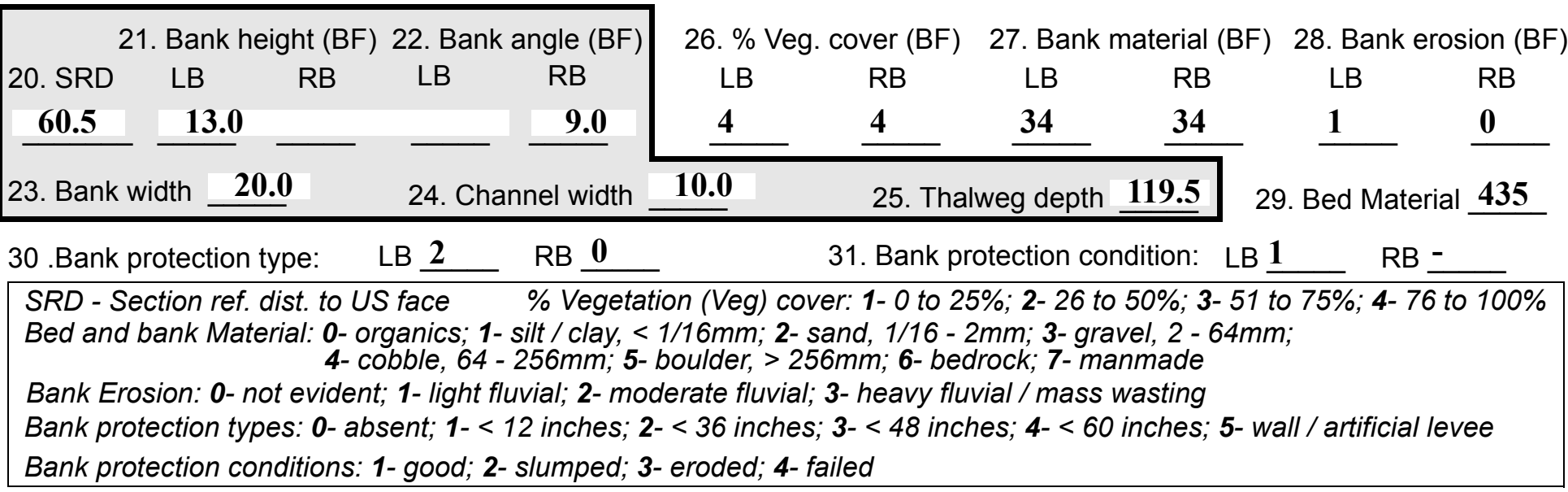

32. Comments (bank material variation, minor inflows, protection extent, etc.):

\#30: Left bank protection extends from 50 feet upstream to the upstream bridge face.

A side channel during high flows exists along the left bank from 470 feet upstream to 60 feet upstream.

A bedrock waterfall exists 500 feet upstream of the bridge. 
33.Point/Side bar present? $\mathbf{Y}$

(Y or N. if $N$ type ctrl-n pb)34. Mid-bar distance: 40 US 35. Mid-bar width: 25

36. Point bar extent: $\underline{\mathbf{9 5}}$ feet $\underline{\mathrm{US}}$ (US, UB) to 10 feet $\underline{\mathbf{D S}}$ (US, UB, DS) positioned $\underline{\mathbf{5 0}} \%$ LB to 100 \%RB

37. Material: $\mathbf{4 3 2}$

38. Point or side bar comments (Circle Point or Side; Note additional bars, material variation, status, etc.):

Areas of this point bar are vegetated.

An additional point bar exists from 470 feet upstream to 120 feet upstream along the left bank. Trees are present on this point bar.

39. Is a cut-bank present? $\mathbf{Y}$ (Y or if $N$ type ctrl-n $c b) \quad 40$. Where? $\mathbf{R B}$ (LB or RB)

41. Mid-bank distance: $\underline{\mathbf{1 8 0}} \quad$ 42. Cut bank extent: $\underline{\mathbf{3 0 0}}$ feet $\underline{\mathrm{US}}$ (US, UB) to $\underline{\mathbf{1 2 4}}$ feet $\underline{\text { US }}$ (US, UB, DS)

43. Bank damage: 1 (1-eroded and/or creep; 2 - slip failure; 3- block failure)

44. Cut bank comments (eg. additional cut banks, protection condition, etc.):

The right bank has an area where 8 feet vertically of exposed material exists. At the base of the exposure is bank material comprised of cobbles and boulders.

45. Is channel scour present? $\mathbf{N}$ (Y or if $N$ type ctrl-n cs) 46. Mid-scour distance: -

47. Scour dimensions: Length ___ Width _ _ Depth : _ _ Position - _ $\%$ LB to _ $\%$ RB

48. Scour comments (eg. additional scour areas, local scouring process, etc.):

NO CHANNEL SCOUR

49. Are there major confluences? $\mathbf{N}$

51. Confluence 1: Distance -

Confluence 2: Distance -

52. Enters on -

Enters on -

54. Confluence comments (eg. confluence name):

NO MAJOR CONFLUENCES
50. How many? -

53. Type(1- perennial; 2- ephemeral)

Type (1-perennial; 2- ephemeral)

\section{Under Bridge Channel Assessment}

55. Channel restraint (BF)? LB 2

56. Height (BF)
LB RB
$\mathbf{2 5 . 0}-$
58. Bank width (BF) -

59. Channel width (Amb) -

(1- natural bank; 2- abutment; 3- artificial levee)

Bed and bank Material: 0- organics; 1- silt / clay, < 1/16mm; 2- sand, 1/16 - 2mm; 3- gravel, 2 - 64mm; 4- cobble, 64 - 256mm; 5- boulder, > 256mm; 6- bedrock; 7- manmade

Bank Erosion: 0- not evident; 1- light fluvial; 2- moderate fluvial; 3- heavy fluvial / mass wasting

64. Comments (bank material variation, minor inflows, protection extent, etc.):

453 
65. Debris and Ice Is there debris accumulation?

$(Y$ or $N)$ 66. Where? $\underline{Y}$

(1- Upstream; 2- At bridge; 3- Both)

67. Debris Potential 1 (1-Low; 2-Moderate; 3- High)

68. Capture Efficiency 3

(1-Low; 2- Moderate; 3- High)

69. Is there evidence of ice build-up? 2

Ice Blockage Potential $\underline{\mathbf{N}}$

(1- Low; 2- Moderate; 3- High)

70. Debris and Ice Comments:

Many trees are leaning in channel, especially in the cut-bank areas. There are also many logs and trees in channel and along banks where the channel bends upstream.

\begin{tabular}{|l|c|c|c|c|c|c|c|c|}
\hline Abutments & $\begin{array}{c}\text { 71. Attack } \\
\angle \mathrm{BF})\end{array}$ & $\begin{array}{c}\text { 72. Slope } \\
(\mathrm{Qmax})\end{array}$ & $\begin{array}{c}\text { 73. Toe } \\
\text { loc. (BF) }\end{array}$ & $\begin{array}{c}\text { 74. Scour } \\
\text { Condition }\end{array}$ & $\begin{array}{c}\text { 75. Scour } \\
\text { depth }\end{array}$ & $\begin{array}{c}\text { 76. Exposure } \\
\text { depth }\end{array}$ & 77. Material & 78. Length \\
\hline LABUT & & $\mathbf{0}$ & $\mathbf{9 0}$ & $\mathbf{2}$ & $\mathbf{2}$ & $\mathbf{0}$ & $\mathbf{0 . 8}$ & $\mathbf{9 0 . 0}$ \\
\hline RABUT & $\mathbf{1}$ & $\mathbf{0}$ & $\mathbf{9 0}$ & & & $\mathbf{2}$ & $\mathbf{0}$ & $\mathbf{4 7 . 5}$ \\
\hline
\end{tabular}

Pushed: $L B$ or RB

Toe Location (Loc.): 0- even, 1- set back, 2- protrudes

Scour cond.: 0- not evident; 1- evident (comment); 2- footing exposed; 3-undermined footing; 4- piling exposed; 5- settled; 6- failed

Materials: 1- Concrete; 2- Stone masonry or drywall; 3- steel or metal; 4- wood

79. Abutment comments (eg. undermined penetration, unusual scour processes, debris, etc.):

80. Wingwalls:

$\begin{array}{lllll}\text { Exist? Material? } & \text { Scour } & \text { Scour Exposure } & & \\ \text { Angle? Length? } & \text { Condition? depth? } & \text { depth? }\end{array}$

USLWW:

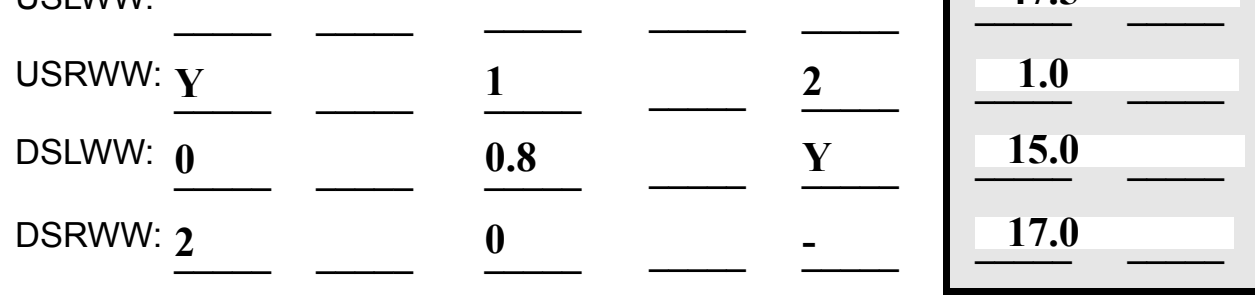

Wingwall materials: 1- Concrete; 2- Stone masonry or drywall; 3- steel or metal; 4- wood

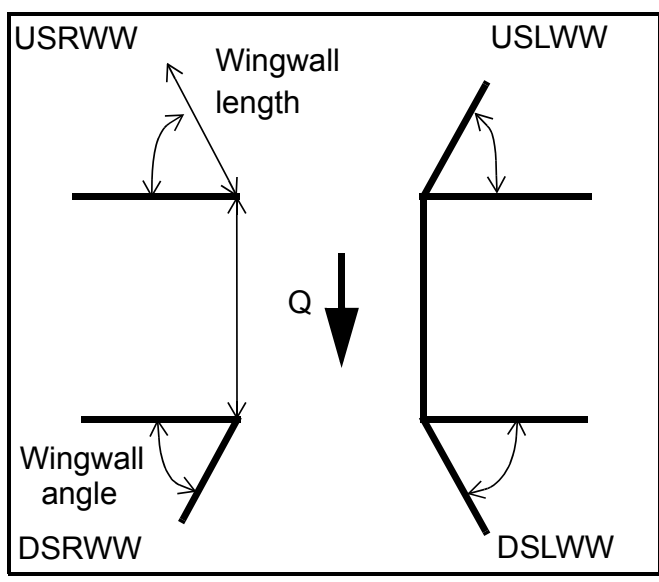

82. Bank / Bridge Protection:

\begin{tabular}{|l|l|l|l|l|l|l|l|c|}
\hline Location & USLWW & USRWW & LABUT & RABUT & LB & RB & DSLWW & DSRWW \\
\hline Type & - & $\mathbf{2}$ & $\mathbf{Y}$ & - & $\mathbf{2}$ & - & - & - \\
\hline Condition & $\mathbf{Y}$ & $\mathbf{0}$ & $\mathbf{2}$ & - & $\mathbf{4}$ & - & - & - \\
\hline Extent & $\mathbf{1}$ & $\mathbf{0 . 4}$ & $\mathbf{0}$ & $\mathbf{2}$ & $\mathbf{0}$ & $\mathbf{0}$ & $\mathbf{0}$ & - \\
\hline
\end{tabular}

Bank / Bridge protection types: 0- absent; 1- < 12 inches; 2- < 36 inches; 3- < 48 inches; 4- < 60 inches; 
83. Wingwall and protection comments (eg. undermined penetration, unusual scour processes, etc.):

-
-
-
-
-
2
1
3
0
-
-

\section{Piers:}

84. Are there piers? $\mathbf{C h}$ (Y or if $N$ type ctrl-n pr)

\begin{tabular}{|l|r|r|r|l|l|l|l|}
\hline \multirow{2}{*}{$\begin{array}{l}85 . \\
\text { Pier no. }\end{array}$} & \multicolumn{3}{|c|}{ width (w) feet } & \multicolumn{3}{c|}{ elevation (e) feet } \\
\cline { 2 - 9 } & w1 & w2 & w3 & e@w1 & e@w2 & e@w3 \\
\hline Pier 1 & & & & $\mathbf{6 0 . 0}$ & $\mathbf{1 0 . 5}$ & $\mathbf{5 0 . 0}$ \\
\hline Pier 2 & $\mathbf{8 . 0}$ & $\mathbf{6 . 5}$ & $\mathbf{6 . 0}$ & $\mathbf{8 5 . 0}$ & $\mathbf{6 5 . 0}$ & - \\
\hline Pier 3 & - & - & - & - & - & - \\
\hline Pier 4 & - & - & - & - & - & - \\
-
\end{tabular}

\begin{tabular}{|l|l|l|l|l|}
\hline Level 1 Pier Descr. & \multicolumn{1}{|c|}{1} & \multicolumn{1}{|c|}{2} & \multicolumn{1}{|c|}{3} & \multicolumn{1}{|c|}{4} \\
\hline 86. Location (BF) & anne & ing & pro- & exte \\
\hline 87. Type & l is & alon & tec- & nds \\
\hline 88. Material & impa & g the & tion & upst \\
\hline 89. Shape & cting & left & begi & ream \\
\hline 90. Inclined? & the & abut & ns in & - \\
\hline 91. Attack $\angle$ (BF) & upst & ment & the & Larg \\
\hline 92. Pushed & ream & - & mid- & e \\
\hline 93. Length (feet) & - & - & - & - \\
\hline 94. \# of piles & left & Upst & dle & stone \\
\hline 95. Cross-members & wing & ream & of & fill \\
\hline 96. Scour Condition & wall & left & the & (type \\
\hline 97. Scour depth & and & wing & wall & -3) is \\
\hline 98. Exposure depth & flow- & wall & and & alon \\
\hline
\end{tabular}

LFP, LTB, LB, MCL, MCM, MCR, RB, RTB, RFP

1- Solid pier, 2- column, 3- bent

1-Wood; 2- concrete; 3- metal; 4- stone

1- Round; 2- Square; 3- Pointed

Y-yes; $N-$ no

$L B$ or $R B$

0- none; 1- laterals; 2- diagonals; 3- both

0- not evident; 1- evident (comment);

2- footing exposed; 3- piling exposed;

4- undermined footing; 5- settled; 6- failed 
99. Pier comments (eg. undermined penetration, protection and protection extent, unusual scour processes, etc.): $\mathrm{g}$ the base of the footing in the channel under the bridge.

$\mathbf{N}$

100.

\section{E. Downstream Channel Assessment}

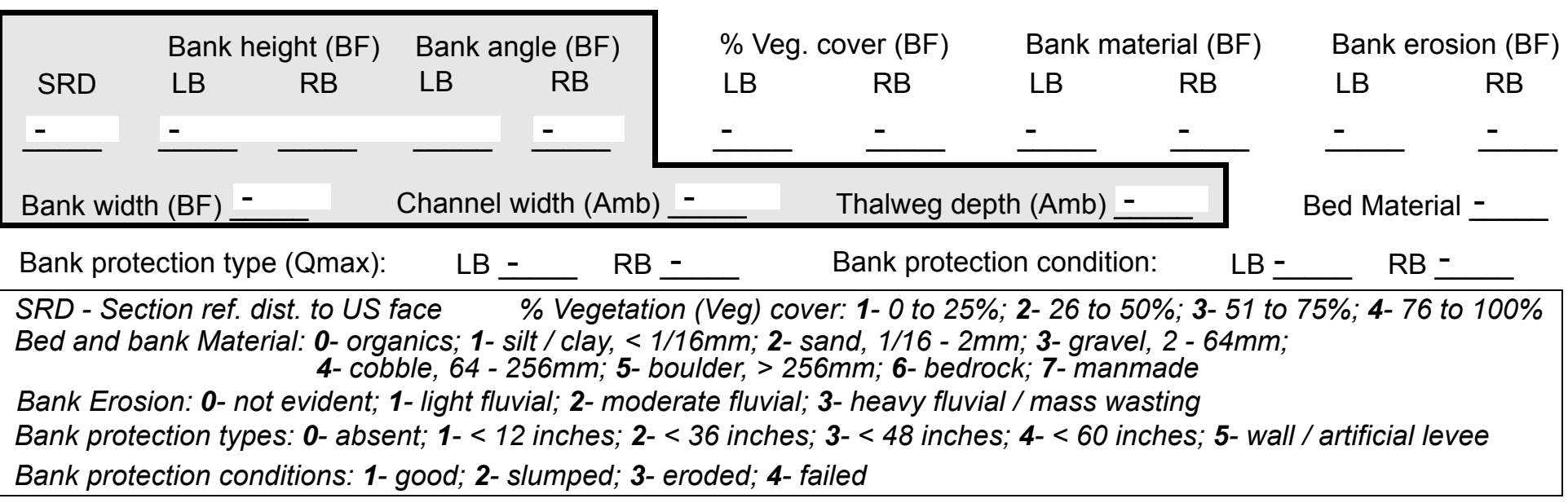

Comments (eg. bank material variation, minor inflows, protection extent, etc.):

-

\section{Is a drop structure present? __ ( $Y$ or $N$, if $N$ type ctrl-n $d s) \quad$ 102. Distance: ___ feet}

103. Drop: __ feet 104. Structure material: ___ (1- steel sheet pile; 2- wood pile; 3- concrete; 4- other)

105. Drop structure comments (eg. downstream scour depth): 
106. Point/Side bar present? (Y or N. if N type ctrl-n pb)Mid-bar distance: -

Mid-bar width:

Point bar extent: feet -

(US, UB, DS) to feet (US, UB, DS) positioned $\%$ LB to $\%$ RB Material:

Point or side bar comments (Circle Point or Side; note additional bars, material variation, status, etc.):

S a cut-bank present? $\mathbf{N}$ (Y or if $N$ type ctrl-n cb) Where? $\underline{\mathbf{O}}$ (LB or RB) Mid-bank distance: PIE Cut bank extent: $\underline{\mathbf{R S}}$ feet ___ (US, UB, DS) to feet ___ (US, UB, DS)

Bank damage: (1- eroded and/or creep; 2- slip failure; 3- block failure)

Cut bank comments (eg. additional cut banks, protection condition, etc.):

Is channel scour present? Scour dimensions: Length $\underline{2}$ Width 43 ( $Y$ or if $N$ type ctrl-n cs) Depth: 43 Mid-scour distance: 2 Scour comments (eg. additional scour areas, local scouring process, etc.): 543

2

0

1

Are there major confluences? Confluence 1: Distance rock ( $Y$ or if $N$ type ctrl-n $m c)$ Positioned $\underline{\mathbf{0}} \%$ LB to $\underline{\mathbf{1}} \%$ RB Confluence 2: Distance ent in Enters on is (LB or $R B)$ How many? BedType pres (1-perennial; 2- ephemeral) Enters on cha (LB or RB) Type nnel (1-perennial; 2- ephemeral) Confluence comments (eg. confluence name):

from 310 feet downstream to 450 feet downstream, where a waterfall exists and drops 6 feet vertically.

\section{F. Geomorphic Channel Assessment}

107. Stage of reach evolution Lef
1- Constructed

2- Stable

3- Aggraded

4- Degraded

5- Laterally unstable

6- Vertically and laterally unstable 
108. Evolution comments (Channel evolution not considering bridge effects; See HEC-20, Figure 1 for geomorphic descriptors):

$t$ bank protection extends from end of downstream left wingwall to 20 feet downstream.

$\mathbf{N}$ 


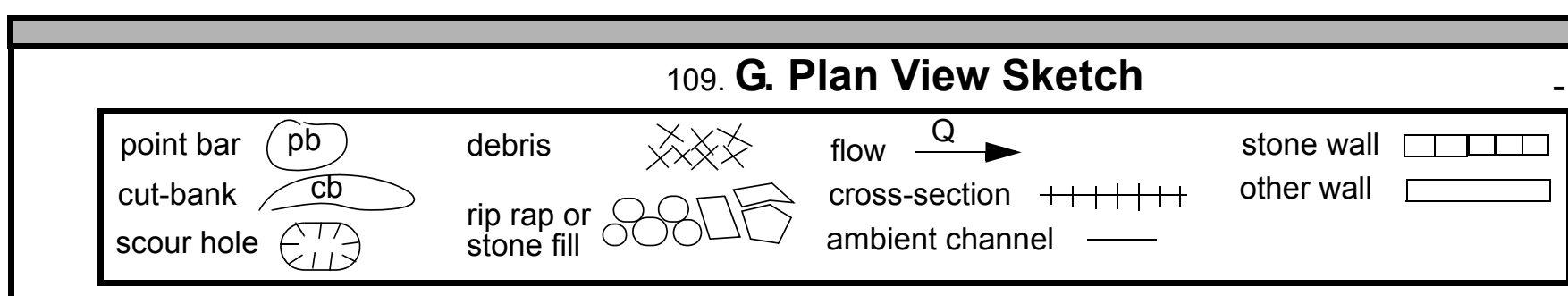


APPENDIX F:

SCOUR COMPUTATIONS 
SCOUR COMPUTATIONS

\begin{tabular}{|c|c|c|c|}
\hline Structure Number: JERITH00350031 & & Town: & JERICHO \\
\hline Road Number: $\quad$ TH 35 & & County: & CHITTENDEN \\
\hline Stream: MILL BROOK & & & \\
\hline Initials ECW & Checked: I & MAI & \\
\hline alysis of contraction scour, live & ed or c & ar wa & \\
\hline $\begin{array}{l}\text { Critical Velocity of Bed Material } \\
\text { VC }=11.21 * 1^{\wedge} 0.1667 * \mathrm{D} 50^{\wedge} 0.33 \text { with } \mathrm{S}\end{array}$ & $\begin{array}{l}\text { converted } \\
=2.65\end{array}$ & to Engl & sh units) \\
\hline (Richardson and others, 1995, p. 28 & eq. 16) & & \\
\hline Approach Section & & & \\
\hline Characteristic & $100 \mathrm{yr}$ & $500 \mathrm{yr}$ & other $\mathrm{Q}$ \\
\hline Total discharge, cfs & 3300 & 4750 & 4330 \\
\hline Main Channel Area, ft2 & 537 & 946 & 881 \\
\hline Left overbank area, ft2 & 0 & 0 & 0 \\
\hline Right overbank area, ft2 & 0 & 74 & 50 \\
\hline Top width main channel, ft & 98 & 113 & 111 \\
\hline Top width L overbank, ft & 0 & 0 & 0 \\
\hline Top width $\mathrm{R}$ overbank, ft & 0 & 44 & 37 \\
\hline D50 of channel, ft & 0.266 & 0.266 & 0.266 \\
\hline D50 left overbank, ft & -- & -- & -- \\
\hline D50 right overbank, ft & -- & -- & -- \\
\hline Y1, average depth, MC, ft & 5.5 & 8.4 & 7.9 \\
\hline $\mathrm{Y}_{1}$, average depth, LOB, ft & $\mathrm{ERR}$ & ERR & ERR \\
\hline Y1, average depth, ROB, ft & ERR & 1.7 & 1.4 \\
\hline Total conveyance, approach & 30391 & 72510 & 64628 \\
\hline Conveyance, main channel & 30391 & 70785 & 63601 \\
\hline Conveyance, LOB & 0 & 0 & 0 \\
\hline Conveyance, ROB & 0 & 1725 & 1027 \\
\hline Percent discrepancy, conveyance & 0.0000 & 0.0000 & 0.0000 \\
\hline Qm, discharge, MC, cfs & 3300.0 & 4637.0 & 4261.2 \\
\hline Q1, discharge, LOB, Cfs & 0.0 & 0.0 & 0.0 \\
\hline Qr, discharge, ROB, cfs & 0.0 & 113.0 & 68.8 \\
\hline Vm, mean velocity $\mathrm{MC}$, ft/s & 6.1 & 4.9 & 4.8 \\
\hline $\mathrm{Vl}$, mean velocity, LOB, ft/s & ERR & ERR & ERR \\
\hline Vr, mean velocity, ROB, ft/s & ERR & 1.5 & 1.4 \\
\hline Vc-m, crit. velocity, MC, ft/s & 9.6 & 10.3 & 10.2 \\
\hline Vc-l, crit. velocity, LOB, ft/s & ERR & ERR & ERR \\
\hline Vc-r, crit. velocity, ROB, ft/s & $\mathrm{ERR}$ & ERR & $\mathrm{ERR}$ \\
\hline Results & & & \\
\hline Live-bed(1) or Clear-Water(0) Contr & action $\mathrm{ScC}$ & our? & \\
\hline Main Channel & 0 & 0 & 0 \\
\hline Left Overbank & $\mathrm{N} / \mathrm{A}$ & $\mathrm{N} / \mathrm{A}$ & $\mathrm{N} / \mathrm{A}$ \\
\hline Right Overbank & $\mathrm{N} / \mathrm{A}$ & $\mathrm{N} / \mathrm{A}$ & $\mathrm{N} / \mathrm{A}$ \\
\hline
\end{tabular}




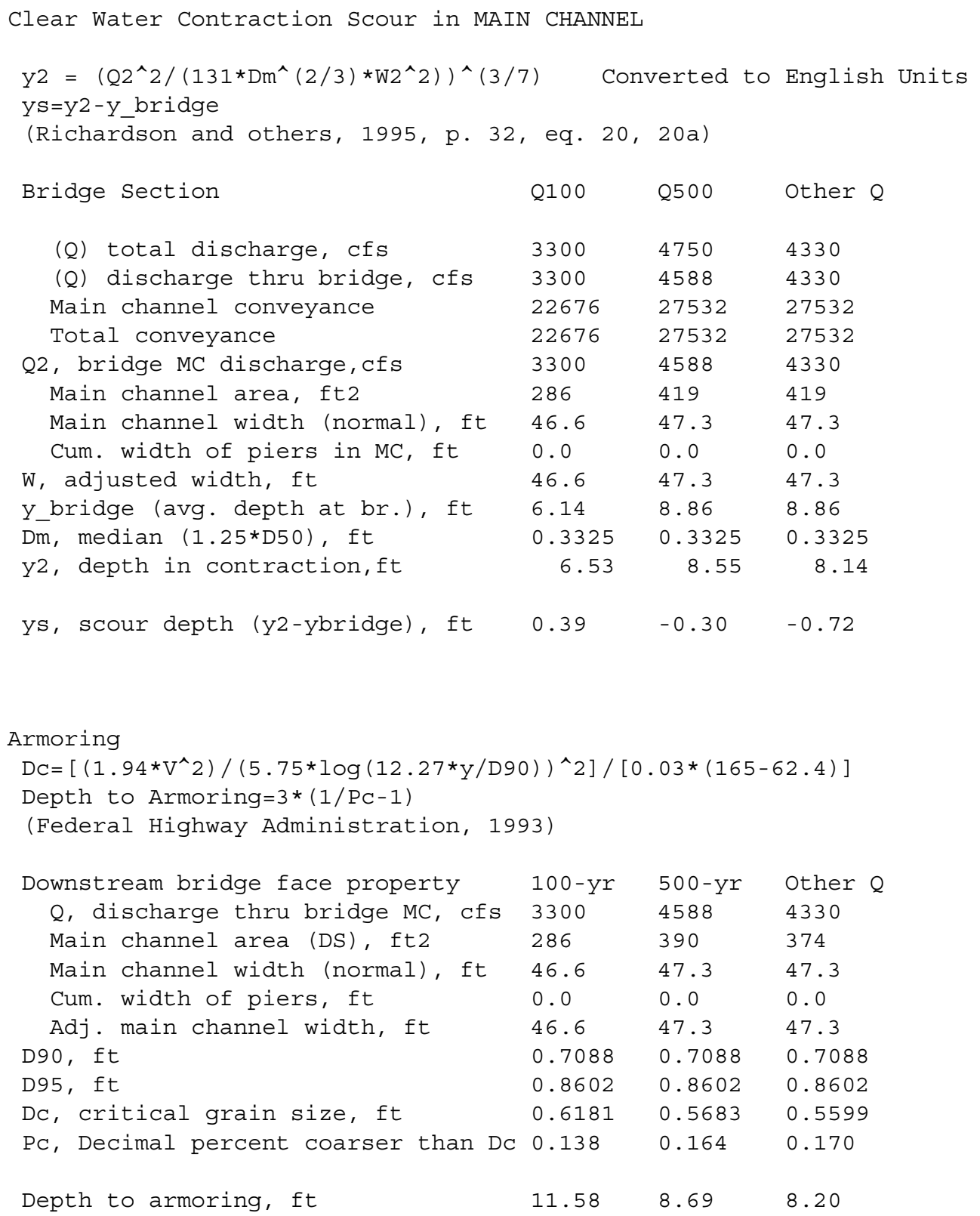




\begin{tabular}{|c|c|c|c|c|}
\hline \multicolumn{5}{|c|}{$\begin{array}{l}\text { Umbrell pressure flow equation } \\
(\mathrm{Hb}+\mathrm{Ys}) / \mathrm{ya}=1.1021 *[(1-\mathrm{w} / \mathrm{ya}) *(\mathrm{Va} / \mathrm{VC})] \wedge 0.6031 \\
\text { (Richardson and other, 1995, p. 144-146) }\end{array}$} \\
\hline & Q100 & Q500 & OtherQ & \\
\hline Q, total, cfs & 3300 & 4750 & 4330 & \\
\hline Q, thru bridge $M C$, cfs & 3300 & 4588 & 4330 & \\
\hline Vc, critical velocity, ft/s & 9.57 & 10.27 & 10.18 & \\
\hline Va, velocity MC approach, ft/s & 6.15 & 4.90 & 4.84 & \\
\hline Main channel width (normal), ft & 46.6 & 47.3 & 47.3 & \\
\hline Cum. width of piers in MC, ft & 0.0 & 0.0 & 0.0 & \\
\hline w, adjusted width, ft & 46.6 & 47.3 & 47.3 & \\
\hline qbr, unit discharge, ft2/s & 70.8 & 97.0 & 91.5 & \\
\hline Area of full opening, ft2 & 286.0 & 419.0 & 419.0 & \\
\hline $\mathrm{Hb}$, depth of full opening, ft & 6.14 & 8.86 & 8.86 & \\
\hline Fr, Froude number, bridge MC & 0 & 0.65 & 0.62 & \\
\hline Cf, Fr correction factor $(<=1.0)$ & 0.00 & 1.00 & 1.00 & \\
\hline **Area at downstream face, ft2 & $\mathrm{N} / \mathrm{A}$ & 390 & 374 & \\
\hline **Hb, depth at downstream face, ft & $\mathrm{N} / \mathrm{A}$ & 8.25 & 7.91 & \\
\hline **Fr, Froude number at DS face & ERR & 0.72 & 0.73 & \\
\hline **Cf, for downstream face $(<=1.0)$ & $\mathrm{N} / \mathrm{A}$ & 1.00 & 1.00 & \\
\hline Elevation of Low steel, ft & 0 & 496.39 & 496.39 & \\
\hline Elevation of Bed, ft & -6.14 & 487.53 & 487.53 & \\
\hline Elevation of Approach, ft & 0 & 500.04 & 499.46 & \\
\hline Friction loss, approach, ft & 0 & 0.34 & 0.45 & \\
\hline Elevation of WS immediately US, ft & 0.00 & 499.70 & 499.01 & \\
\hline ya, depth immediately US, ft & 6.14 & 12.17 & 11.48 & \\
\hline Mean elevation of deck, ft & 0 & 499.33 & 499.33 & \\
\hline w, depth of overflow, ft $(>=0)$ & 0.00 & 0.37 & 0.00 & \\
\hline Cc, vert contrac correction $(<=1.0)$ & 1.00 & 0.93 & 0.94 & \\
\hline$* * \mathrm{Cc}_{\mathrm{C}}$, for downstream face $(<=1.0)$ & ERR & 0.907833 & 0.903517 & \\
\hline Ys, scour w/Chang equation, ft & $\mathrm{N} / \mathrm{A}$ & 1.31 & 0.75 & \\
\hline Ys, scour w/Umbrell equation, ft & $\mathrm{N} / \mathrm{A}$ & -0.43 & -0.78 & \\
\hline
\end{tabular}




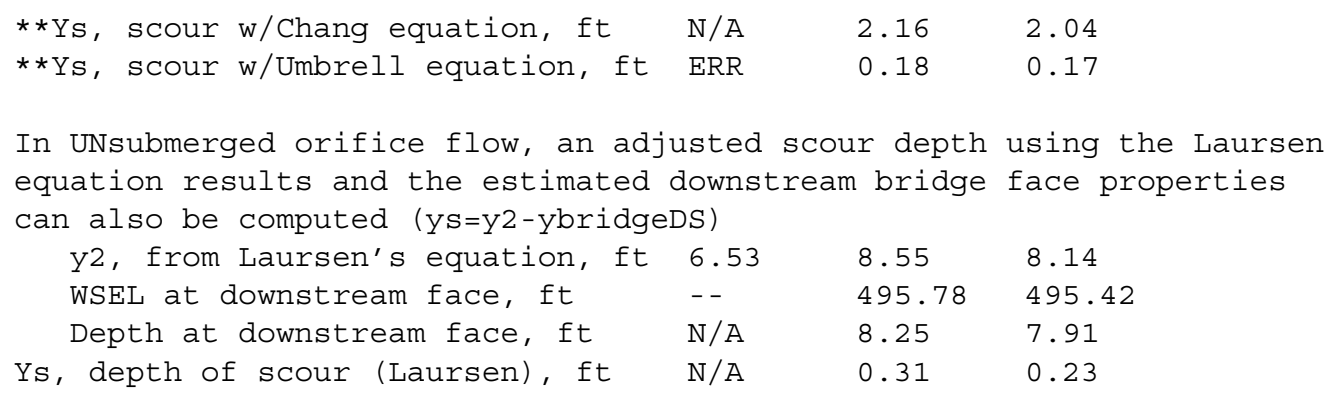

Abutment scour

Froehlich's Abutment Scour

$\mathrm{Ys} / \mathrm{Y} 1=2.27 * \mathrm{~K} 1 * \mathrm{~K} 2 *\left(\mathrm{a}^{\prime} / \mathrm{Y} 1\right)^{\wedge} 0.43 * \mathrm{Fr} 1 \wedge 0.61+1$

(Richardson and others, 1995, p. 48, eq. 28)

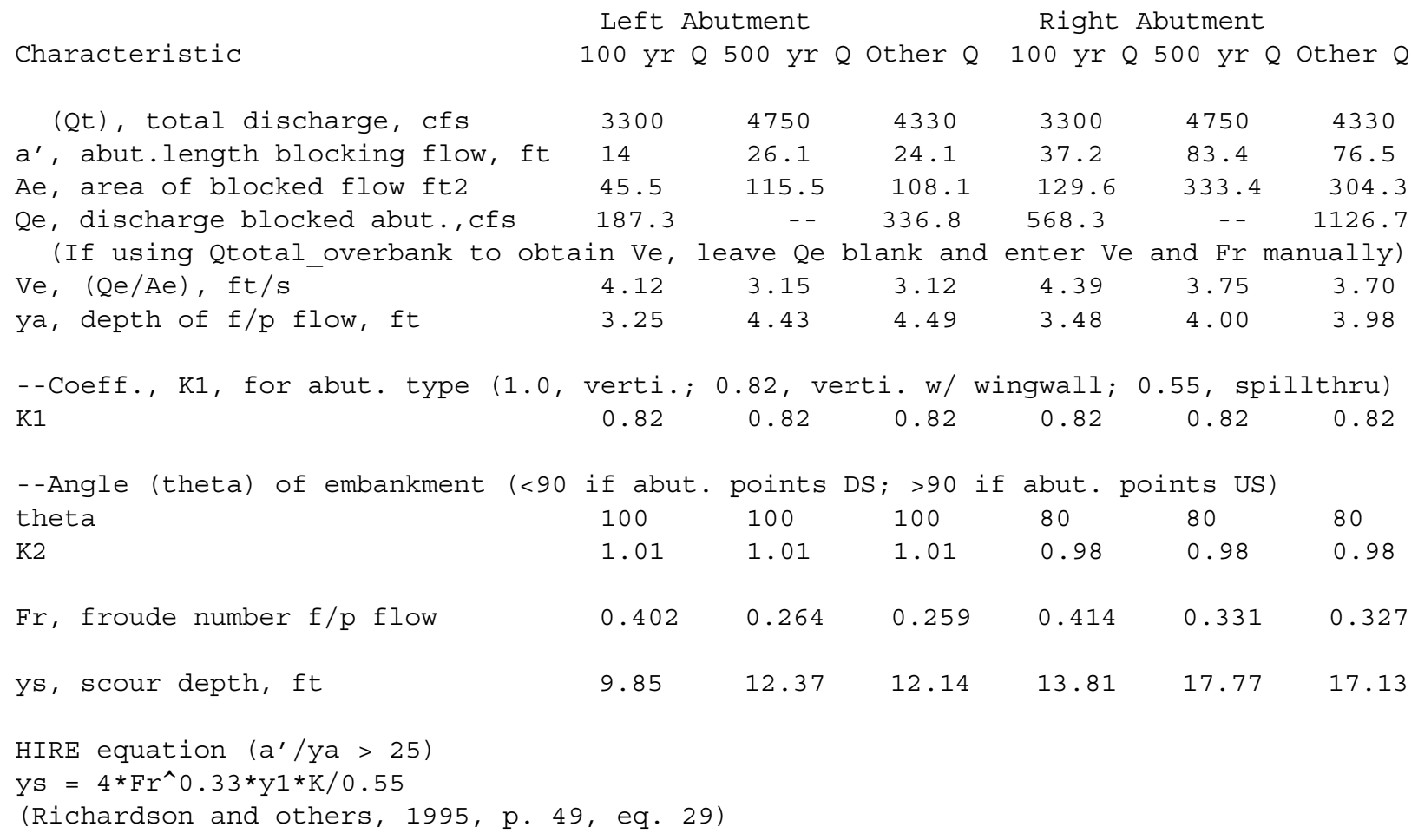




\begin{tabular}{|c|c|c|c|c|c|c|}
\hline$a^{\prime}$ (abut length blocked, ft) & 14 & 26.1 & 24.1 & 37.2 & 83.4 & 76.5 \\
\hline y1 (depth f/p flow, ft) & 3.25 & 4.43 & 4.49 & 3.48 & 4.00 & 3.98 \\
\hline$a^{\prime} / y^{\prime}$ & 4.31 & 5.90 & 5.37 & 10.68 & 20.86 & 19.23 \\
\hline Skew correction (p. 49, fig. 16) & 1.02 & 1.02 & 1.02 & 0.97 & 0.97 & 0.97 \\
\hline Froude no. f/p flow & 0.40 & 0.26 & 0.26 & 0.41 & 0.33 & 0.33 \\
\hline Ys w/ corr. factor $\mathrm{K} 1 / 0.55$ : & & & & & & \\
\hline vertical & ERR & ERR & ERR & ERR & ERR & ERR \\
\hline vertical w/ ww's & ERR & ERR & ERR & ERR & ERR & ERR \\
\hline spill-through & ERR & ERR & ERR & ERR & ERR & ERR \\
\hline Abutment riprap Sizing & & & & & & \\
\hline Isbash Relationship & & & & & & \\
\hline $\mathrm{D} 50=\mathrm{Y}^{*} \mathrm{~K} * \mathrm{Fr} \mathrm{r}^{\wedge} 2 /(\mathrm{SS}-1)$ and $\mathrm{D} 50=\mathrm{Y}^{*} \mathrm{~K} *$ & $\left.\wedge^{\wedge} 2\right)^{\wedge} 0$ & $/(S S-1)$ & & & & \\
\hline (Richardson and others, 1995, p11 & eq. $\varepsilon$ & & & & & \\
\hline Characteristic & Q100 & Q500 & Other $Q$ & Q100 & Q500 & Other Q \\
\hline Fr, Froude Number & 0.82 & 0.72 & 0.73 & 0.82 & 0.72 & 0.73 \\
\hline$y$, depth of flow in bridge, ft & 6.14 & 8.25 & 7.91 & 6.14 & 8.25 & 7.91 \\
\hline Median Stone Diameter for riprap & $\therefore$ left & butment & & right & abutment, & ft \\
\hline Fr $<=0.8$ (vertical abut.) & ERR & 2.64 & 2.61 & $E R R$ & 2.64 & 2.61 \\
\hline Fr>0.8 (vertical abut.) & 2.43 & ERR & ERR & 2.43 & ERR & ERR \\
\hline Fr<=0.8 (spillthrough abut.) & ERR & 2.31 & 2.27 & $\mathrm{ERR}$ & 2.31 & 2.27 \\
\hline Fr>0.8 (spillthrough abut.) & 2.15 & ERR & ERR & 2.15 & ERR & $E R R$ \\
\hline
\end{tabular}


